\title{
Water Resources of the
}

Salmon Falls Creek Basin

Idaho-Nevada

GEOLOGICAL SURVEY WATER-SUPPLY PAPER 1879-D

Prepared in cooperation with the

U.S. Bureau of Reclamation and Idaho Department of Reclamation

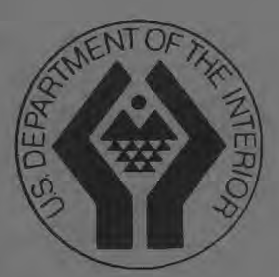




\section{Water Resources of the}

Salmon Falls Creek Basin

\section{Idaho-Nevada}

7y E. G. CROSTHWAITE

CONTRIBUTIONS TO THE HYDROLOGY OF THE UNITED STATES

GEOLOGICAL SURVEY WATER-SUPPLY PAPER 1879-D

Prepared in cooperation with the

U.S. Bureau of Reclamation and

Idaho Department of Reclamation

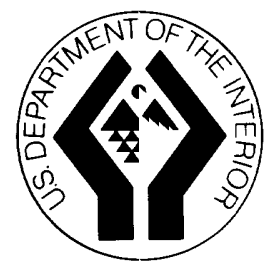




\title{
UNITED STATES DEPARTMENT OF THE INTERIOR
}

STEWART L. UDALL, Secretary

\author{
GEOLOGICAL SURVEY
}

William T. Pecora, Director

For sale by the Superintendent of Documents, U.S. Government Printing Office Washington, D.C. 20402 - Price 25 cents (paper cove-) 


\section{CONTENTS}

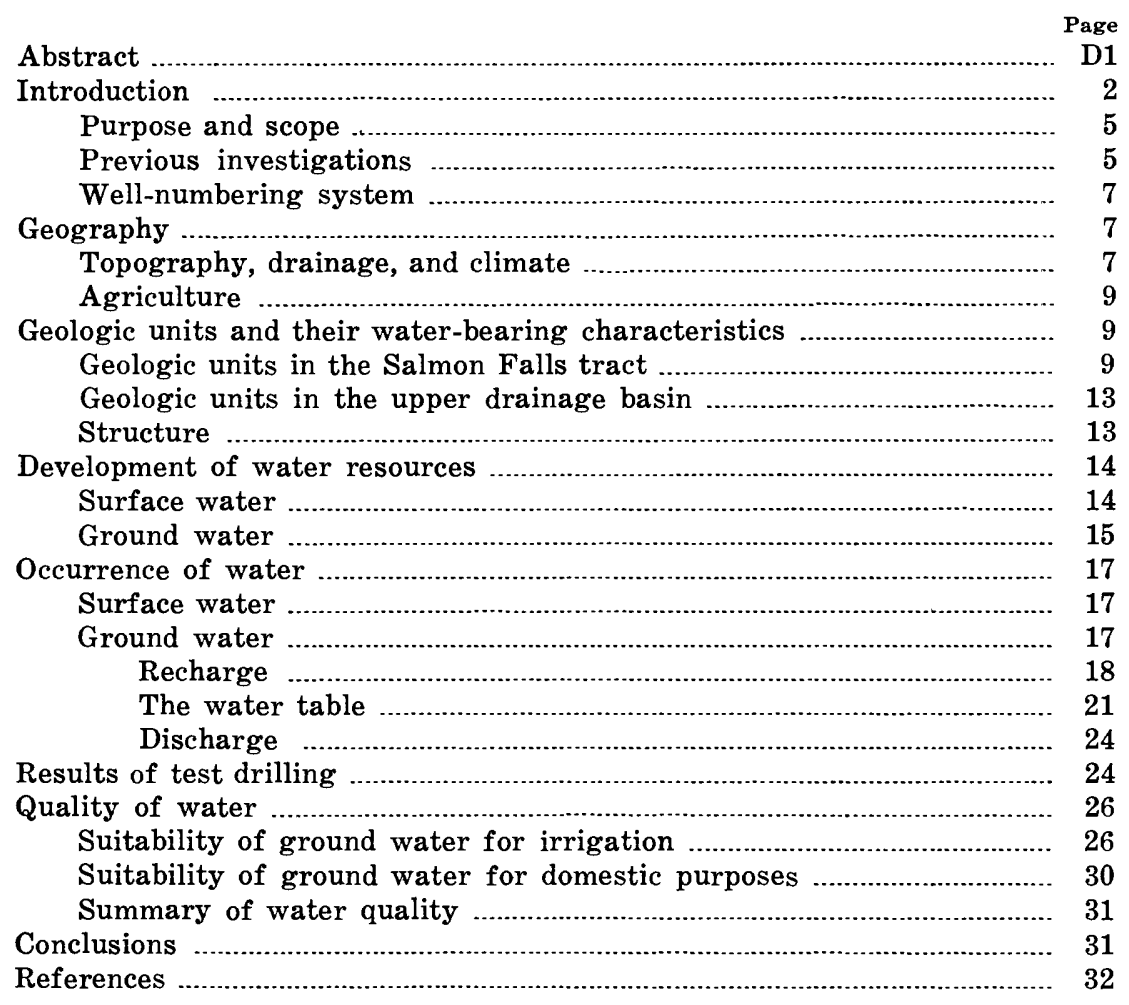

\section{ILLUSTRATIONS}

Figure 1. Index map showing location of study area

2. Map showing annual precipitation in the Salmon Falls Creek basin and irrigated land in the Salmon Falls tract .............. 4

3. Sketch showing well-numbering system ..................................... 6

4. Geologic map of the Salmon Falls tract ................................... 10

5. Well-location and water-level-contour map .............................. 22

6. Generalized lithologic logs of wells drilled for this investigation

7. Graph showing salinity and sodium classification of water for irrigation 


\section{TABLES}

TABLE 1. Summary of the physical and hydrologic character of rock

2. Quantity and disposition of surface water available to the

Salmon Falls tract

3. Estimated ground-water recharge to the Salmon Falls tract

4. Test and observation wells drilled in the Salmon Falls tract

5. Chemical analyses of ground water from the Salmon Falls Creek basin, Idaho 


\title{
CONTRIBUTIONS TO THE HYDROLOGY \\ OF THE UNITED STATES
}

\section{WATER RESOURCES OF THE SALMON FALLS CREEK BASIN, IDAHO-NEVADA}

\author{
By E. G. Crosthwaite
}

ABSTRACT

The northern part of the Salmon Falls Creek basin, referred to is the Salmon Falls tract, contains a large acreage of good agricultural land, but the surface-water supply is inadequate to develop the area fully. Attempts to develop ground water for irrigation have been successful only locally. Specific capacities of wells drilled for irrigation and for test purposes ranged from less than 0.5 to 70 gallons per minute per foot of drawdown.

The surface-water supply averages 107,000 acre-feet annually, of which about 76,000 acre-feet is diverted for irrigation.

The Idavada Volcanics, the most widespread and oldest water-bearing formation in the Salmon Falls tract, consists of massive, dense, thick flows and blankets of welded silicic tuff with associated fine- to coarse-grained ash, clay, silt, sand, and gravel. Fault zones and jointed rock yield large amounts of water to wells, but massive nonjointed units yield little water. Sand, tuff, and ash beds yield moderate quantities of water. Clay, sandy clay, sand, and pea gravel occur in topographic lows on the Idavada Volcanics. The finegrained sediments yield little water to wells, but the gravel yields moderate quantities.

Vesicular porphyritic irregularly jointed olivine basalt flows, which overlie the Idavada Volcanics, underlie almost all the Salmon Falls tract. Lenticular fine-grained sedimentary beds as much as 15 feet thick separate some of the flows. Joints and contacts between flows yield small to moderate amounts of water to wells.

Alluvial and windblown deposits blanket most of the tract. Where they occur below the water table, the alluvial deposits yield adequate supplies for stock and domestic wells. Perched water in the alluvium along Deep Creek supplies some stock and domestic wells during most years.

Ground-water supplies adequate for domestic and stock use can be obtained everywhere in the tract, but extensive exploration has disccuered only five local areas where pumping ground water for irrigation is presently economically feasible. About 8,000 acre-feet was withdrawn for all uses in 1960 . 
Natural discharge of ground water is northward - toward the Twin Falls South Side Project and the Snake River - and is provisionally estimated to be 115,000 acre-feet annually.

Ground water in the Salmon Falls tract has a mediur to high salinity hazard and a low sodium hazard. The salinity does not appear to affect crops presently grown in the tract.

The southern part of the Salmon Falls Creek basin, roferred to as the upper drainage basin, has little agricultural development and is used mostly for grazing livestock. Silicic volcanic rocks and tuffaceous sedimentary rocks of Tertiary age and alluvial deposits yield water to livestcck, domestic, and commercial wells.

\section{INTRODUCTION}

The Salmon Falls Creek basin is in southern Twin Falls County, Idaho, and northern Elko County, Nev. (fig. 1). To facilitate discussion, the basin is here divided into two parts, tre Salmon Falls tract and the "upper drainage basin." The area of principal interest and detailed study is the Salmon Falls tract in Twin Falls County. The tract, topographically a broad rolling plain, makes up the project lands of the Salmon Falls Canal Co., Ltd. It is bounded on the west by the canyon of Salmon Falls Creek, $n$ the north by the High Line Canal of the Twin Falls South Side Project, on the east by the Rock Creek Hills, and on the south by a series of unnamed hills (fig. 2). The "upper drainage basin" lies mostly in Nevada and consists of several basins enclosed by mountain ranges.

Salmon Falls Dam, in sec. 18, T. 14 S., R. 15 E., v'as constructed in 1909-11 to store the waters of Salmon Falls Creek for irrigation in the Salmon Falls tract. The dam impounds water in a reservoir with about 182,000 acre-feet of usable capacity. First delivery of water to farms was in 1911. The original plan was to irrigate a project area of 150,000 acres, but the water supply was so inadequate that by 1918 the project area was reduced to 35,000 acres. The actual number of acres irrigated has fluctuated each year according to the available annual water supply, and in recent years it has ranged from about 12,000 to 30,000 acres. mo obtain additional water, the Salmon Falls Canal Co. in 1947 p'rrchased about 8,000 acre-feet of decreed water rights from water users in the upper drainage basin in Nevada. Even with this additional supply the project has not been able to supply all irrigable lands.

The canal company has sought an additional water source for many years. Among the sources considered have been the transmountain diversion of water from the Bruneau River basin to the west and the diversion of uncommitted water frcm Rock Creek on the northeast. Thus far no attempt has been made to acquire water by either diversion method. 
SALMON FALLS CREEK BASIN, IDAHO-NEVADA

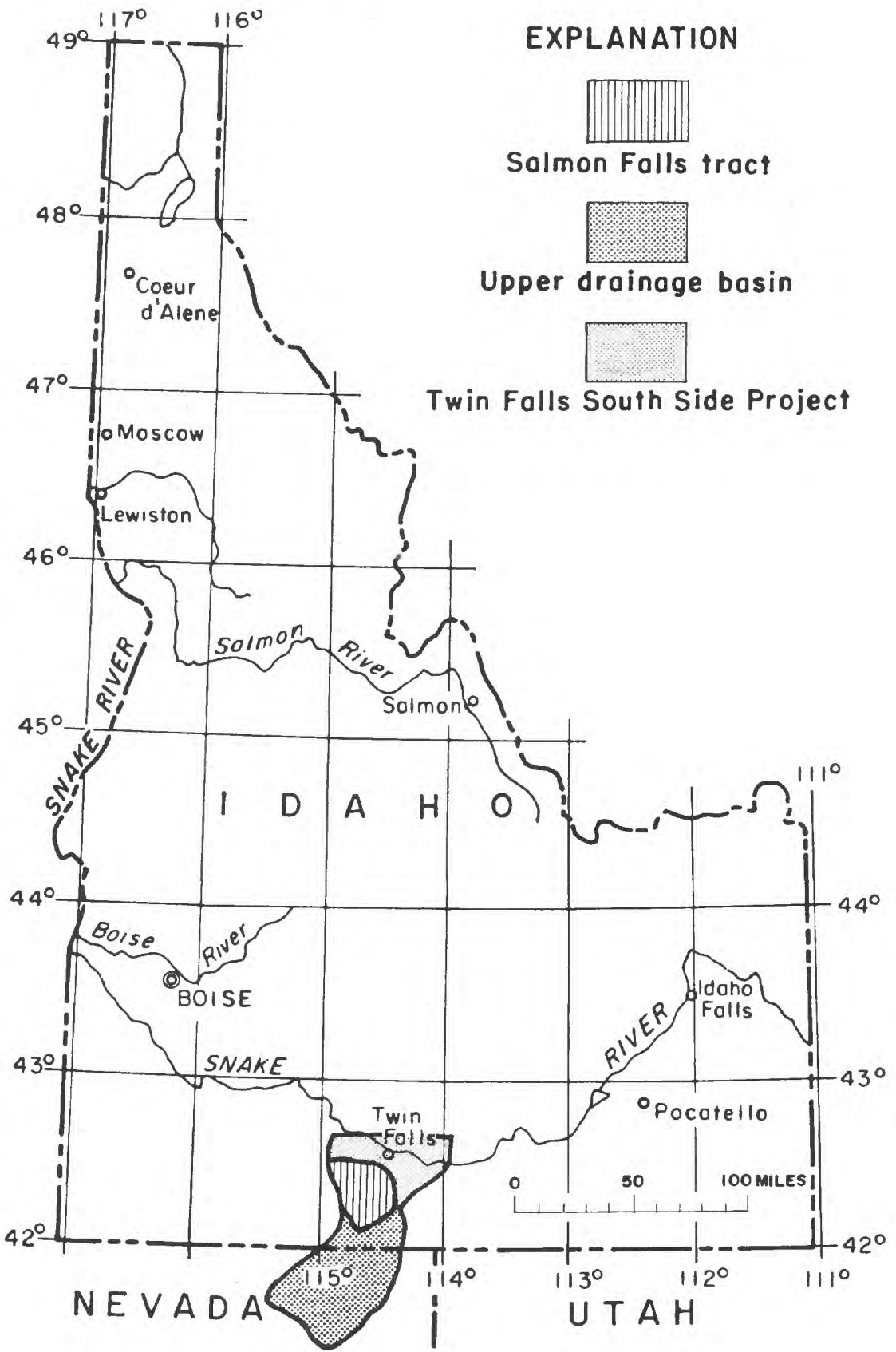

Figure 1. - Index map showing location of study area. 


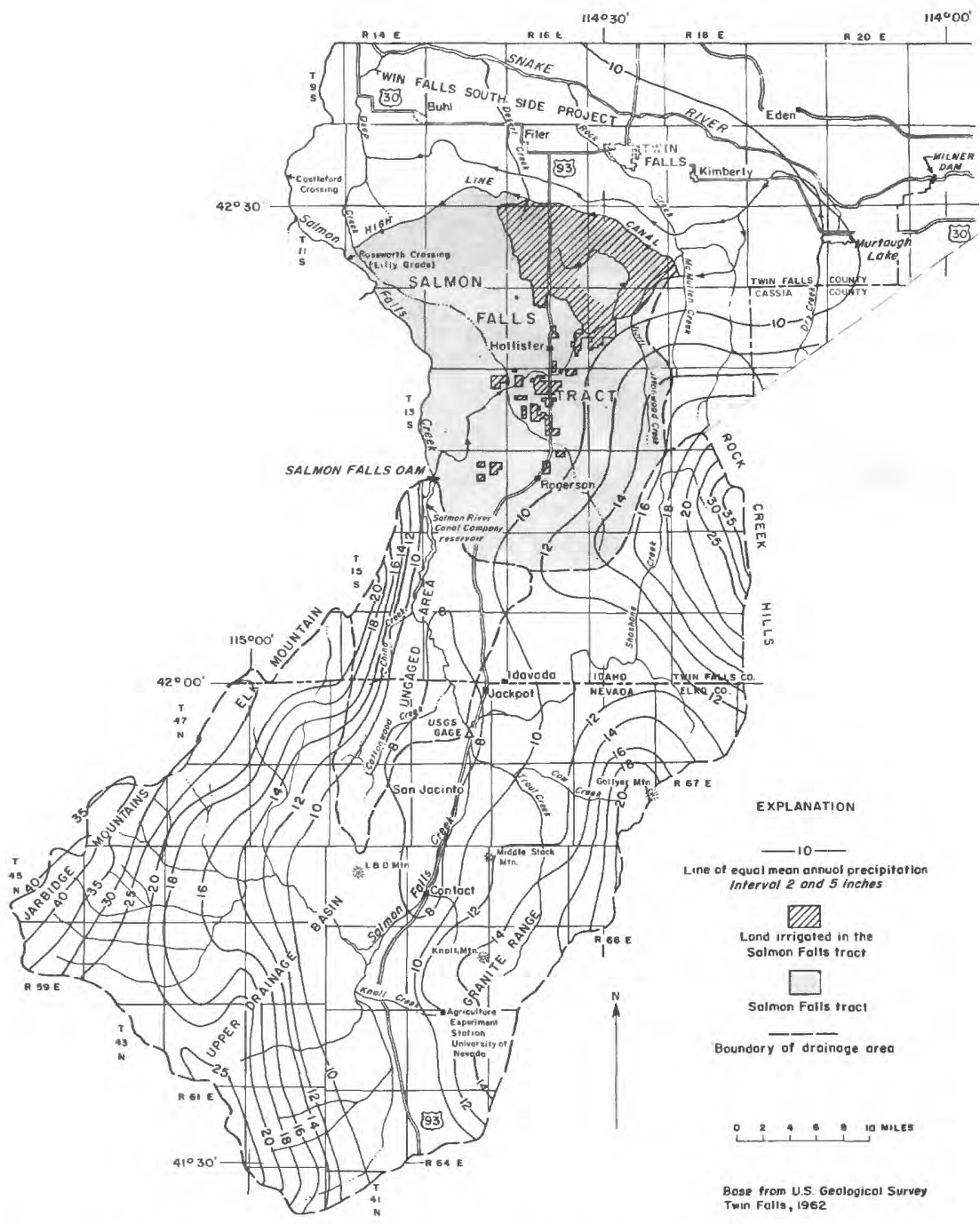

FIGURE 2.- Annual precipitation in the Salmon Falls Creek basin and irrigated land in the Salmon Falls tract. Precipitation data after Thomas, Broom, and Cummans (1963).

The great interest in the development of ground water for irrigation in the past 15 years has prompted many farmers to explore for ground water in the Salmon Falls tract. These efforts have been only partly successful owing to generally low permeability of the aquifers and to great depth to water in much of the area.

In 1959 the U.S. Bureau of Reclamation requested the U.S. Geological Survey to make a study of the hydrology of the Salmon 
Falls Creek basin to facilitate the Bureau of Reclamation's planning for multipurpose development in the upper Snake River basin. The Idaho Department of Reclamation also cooperated in the study to help obtain water-management data for their needs.

\section{PURPOSE AND SCOPE}

The purpose of this report is to describe the water resour?es of the Salmon Falls Creek basin. This report summarizes the data collected during investigations made by the Geological Survey and presents an interpretation of this data. The total natural water supply to the Salmon Falls Creek basin is estimated from measurements of streamflow and precipitation-water yield relationships developed in other studies (Eakin and others, 1951; Murdorff, Crosthwaite, and Kilburn, 1964). Ground-water conditions in the northern part of the basin are evaluated by use of data from test wells; logs and records of existing wells, and knowledge of general surface and subsurface geologic conditions. Ground-water conditions were not evaluated in the upper drainage basin because of the lack of development of the resource. However, data were collected from stock-watering wells, and publications on the geology of the area were consulted.

\section{PREVIOUS INVESTIGATIONS}

Several studies have been made of the occurrence and utilization of natural water resources in the Salmon Falls basin. Hovever, most are now obsolete, and none has provided the needed information about the basin as a whole or about the ground-water conditions in the Salmon Falls tract.

Russell (1902, p. 177) was the first to write about ground water in the Salmon Falls tract, although he did not actually visit the area. Stearns, Crandall, and Steward (1938, p. 207-208) brief y discussed flowing wells east of Hollister and estimated the annual recharge to ground water in the Salmon Falls tract. O. E. Meinzer made a reconnaissance of part of the upper drainage basin in 1921, during which time he observed several springs, both thermal and cold. His unpublished study noted wells at the Vineyard Ranch, a few miles south of Contact, Nev.

Schrader (1912) made a geologic reconnaissance of the Contact and Elk Mountain mining districts in the upper drainage basin. His report contains a description of the rocks in the mining districts and a sketch map of the geology. Upon reexamining the Contact district in 1930 (Schrader, 1935), he republished the same geologic map of his earlier report. 
The Idaho State Engineer made seepage-loss studies of several sections of the canal system in 1912-13. (See Rcbinson, 1913; Wing, 1915.) Other seepage studies of the canal system were made by Warnick and Johnson (1955) and by the U.S. Department of Agriculture (1956).

The U.S. Bureau of Reclamation (1959) prepared a report on the possibility of using Snake River water to supply the lower, northern part of the tract and to develop new land. The U.S. Geological Survey (Fowler, 1960) made a reconnaissance study of the ground-water resources of the Salmon Falls tract.

Streamflow records collected since 1909 in the drainage basin have been published in the annual reports of the surface-water records of the Geological Survey. (See U.S. Geological Survey, 1956, 1963.)
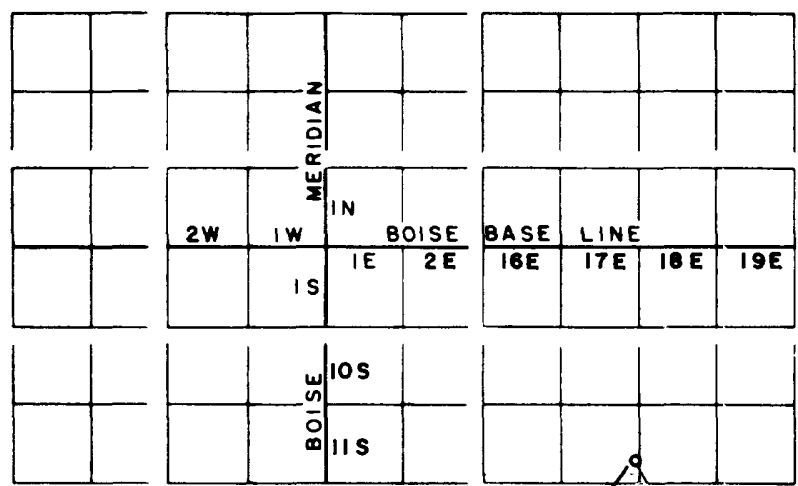

WELL IIS-17E-25ddI

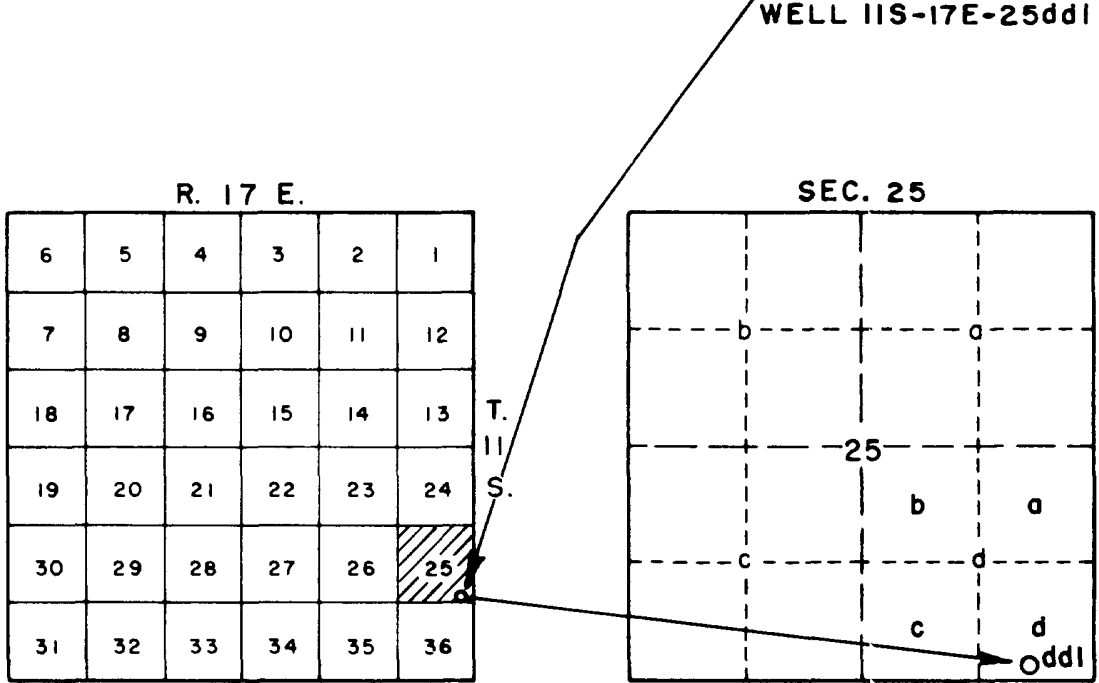

FiguRE 3. - Well-numbering system. 
The canal company has kept records of quantities of water diverted from the reservoir, quantities delivered to the farmers' headgates, acres irrigated between 1911 and 1936, and other data necessary for operation of the canal system. Many of these data appear in the annual reports furnished to canal company stockholders. The company has also made several studies of water use in the upper drainage basin.

\section{WELL-NUMBERING SYSTEM}

The well-numbering system used by the U.S. Geological Sirvey in Idaho indicates the location of wells within the official rectangular subdivisions of the public lands, with reference to the Boise base line and meridian. The first two segments of the ntmber designate the township and range. The third segment gives the section number and two letters and a numeral which indicate the quarter section, the 40 -acre tract, and the serial number $c f$ the well within the tract, respectively. Quarter sections are lettered $a, b, c$, and $d$ in counterclockwise order from the northeast quarter of each section (fig. 3 ). Within the quarter sections, 40-acre tracts are lettered in the same manner. Well 11S-17E-25dd1 is in the $\mathrm{SE} 1 / 4, \mathrm{SE} 1 / 4$, sec. $25, \mathrm{~T} .11 \mathrm{~S} ., \mathrm{R} .17 \mathrm{E}$., and is the first well recorded in that tract.

\section{GEOGRAPHY}

TOPOGRAPHY, DRAINAGE, AND CLIMATE

The topography of the Salmon Falls Creek basin is vrried. The headwater areas are characterized by high rugged mountain ranges. The Jarbidge Mountains, for example, rise to an altitude of 10,185 feet above sea level, some 4,000-5,000 feet above the lowlands. Many other mountains that rim the upper basin are more than 8,000 feet in altitude. Within the upper drainage basin are several subbasins of low to moderate relief. The middle part of the upper drainage basin consists, for the most part, of low ridges or of rough, broken terrain. To the north the Salmon Falls tract is a gently rolling plain mantled by windblown sediments. The tract is about 25 miles long, has a maximum width of about 25 miles. and is a southward extension of the Snake River Plain. Altitudes in the tract range from about 4,100 to 5,000 feet.

All drainage of the Salmon Falls Creek basin is tributary to the Snake River. Most of the streams are intermittent for much of their course, but many have perennial reaches in the headwaters. Salmon Falls Creek is perennial for its entire length, and in its middle course occupies a deep narrow canyon. At the soutrwest corner of the Salmon Falls tract, the canyon widens into a narrow valley that is the reservoir area behind Salmon Falls Dam. From the dam to the Snake River, the creek again flows through a deep narrow canyon. 
Because of the wide range in both topography and altitude in the basin, the climate in the basin is varied. In general, the lowlands have hot dry summers and cold subhumid winters. The highlands generally have warm semiarid summers and ccld humid winters. Climatologic records from U.S. Weather Bureau stations $(1932,1937,1957,1958,1962 \mathrm{a}, \mathrm{b}, 1963 \mathrm{a}, \mathrm{b}, 1964 \mathrm{a}, \mathrm{b}, \mathrm{c}, 1965)$ in and near the basin are shown in the following table. The distribution of precipitation is shown in figure 2 .

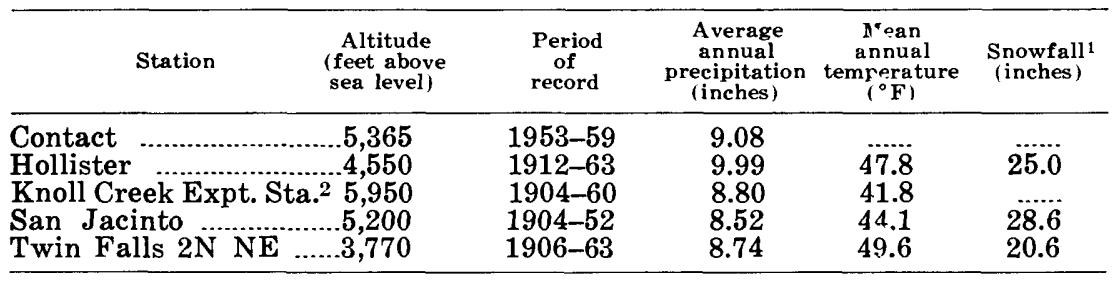

1 Record missing for some years.

2Data furnished by Agriculture Research Service, U.S. Dept. of Agriəulture, Reno, Nev., March 1961.

The average annual precipitation is about 10 inches at Hollister, near the center of the extensively cultivated part of the basin. Precipitation on the high mountains probably exceads 40 inches, but records are scanty. The average annual frost-free period at Hollister is about 111 days, and an average period between the earliest and latest reported temperatures of $24^{\circ} \mathrm{F}$ is 180 days (U.S. Weather Bureau, 1959, p. 4).

There are no evaporation and transpiration data for the Salmon Falls Creek basin. Comparison of evaporation data compiled by Stearns, Crandall, and Steward (1938, p. 15) and by Kohler, Nordenson, and Baker (1959, pls. 2, 3), and recorded pen evaporation at Weather Bureau stations elsewhere in Idaho, indicates that the average annual evaporation from free-water surfaces in this area is about 38 inches.

Evapotranspiration - the water taken from tl $:$ ground and returned to the air by plants, and the water evaporated from soil, surface water, and snow - ranges from 6 to 9 inches annually in areas of sparse vegetation, such as in this basin, according to Blaney and Criddle (1949, p. 9). No attempt was made to evaluate evapotranspiration from forested areas because they are of minor extent in the Salmon Falls Creek basin.

Jensen and Criddle (1952, p. 12) estimated annual evapotranspiration from the principal areas of irrigated croplands in the Salmon Falls tract to be 17.3 inches. In their estimates they considered water derived from effective precipitation and water applied for irrigation. Simons (1953, p. 64) estimated the annual 
evapotranspiration from the irrigated cropland of the area to be 19 inches. He did not include growing-season precipitation in his estimate. Growing-season precipitation averages about 2.5 inches annually, nearly all of which is evaporated or transpired. Had Simons included growing-season precipitation, his estimate of total evapotranspiration would have been about 21 or 21.5 inches. In the present report the annual evapotranspiration from irrigated croplands is considered to average 20 inches, of which 2 inches is supplied by precipitation and the remainder by irrigation.

\section{AGRICULTURE}

The principal crops grown in the northern part of the Salmon Falls Creek basin are hay, grain, and beans. Some potatoes, peas, corn, sugar beets, and clover and alfalfa for seed are also grown. Beef cattle are an important source of income, and dairy products, a minor source. The nonirrigated land in the tract and in large parts of the upper drainage basin is used for grazing. Much of the nonirrigated land in the tract has been cleared and seeded to drought-resistant grasses for livestock forage. A few areas in Salmon Falls Creek basin are dry farmed, especially the lower western slopes of the Rock Creek Hills. Irrigated acreage varies from year to year in response to estimates of the amounts of water that will be available.

\section{GEOLOGIC UNITS AND THEIR WATER-BEARING} CHARACTERISTICS

The geologic materials underlying Salmon Falls Creek basin range from nearly impermeable to highly permeable. Rock types are diverse and include granite, limestone, quartzite, shale, rhyolitic and basaltic volcanic rocks, ash, pumice, clay, silt, sand, and gravel. Although all types are present in the upper drainage basin, granite and shale are not known to occur within the Salmon Falls tract. Limestone and quartzite crop out in one small area along the southeast edge of the tract.

\section{GEOLOGIC UNITS IN THE SALMON FALLS TRACT}

The surface distribution of the rock units in the Salmon Falls tract and along the western part of the Rock Creek Hills adjacent to the tract is shown in figure 4 . The water-bearing character of these rocks is summarized in table 1 .

Most of the consolidated rocks consist of volcanic flows and welded tuffs of late Tertiary and Holocene age. The oldest of these flows and welded tuffs are of silicic composition and are Pliocene in age. They underlie the Salmon Falls tract and are exposed in the hills along the east and south sides of the tract and in the canyon of Salmon Falls Creek. Interbedded with the silicic volcanic rocks 
are beds of ash, clay, and sand. These rocks - the Idavada Volcanics (Malde and Powers, 1962, p. 1200) - probably overlie limestone and quartzite of Paleozoic age. Overlying the Idavada Volcanics at many places are lenticular beds of clay, silt, sand, and gravel with some ash admixed at places.

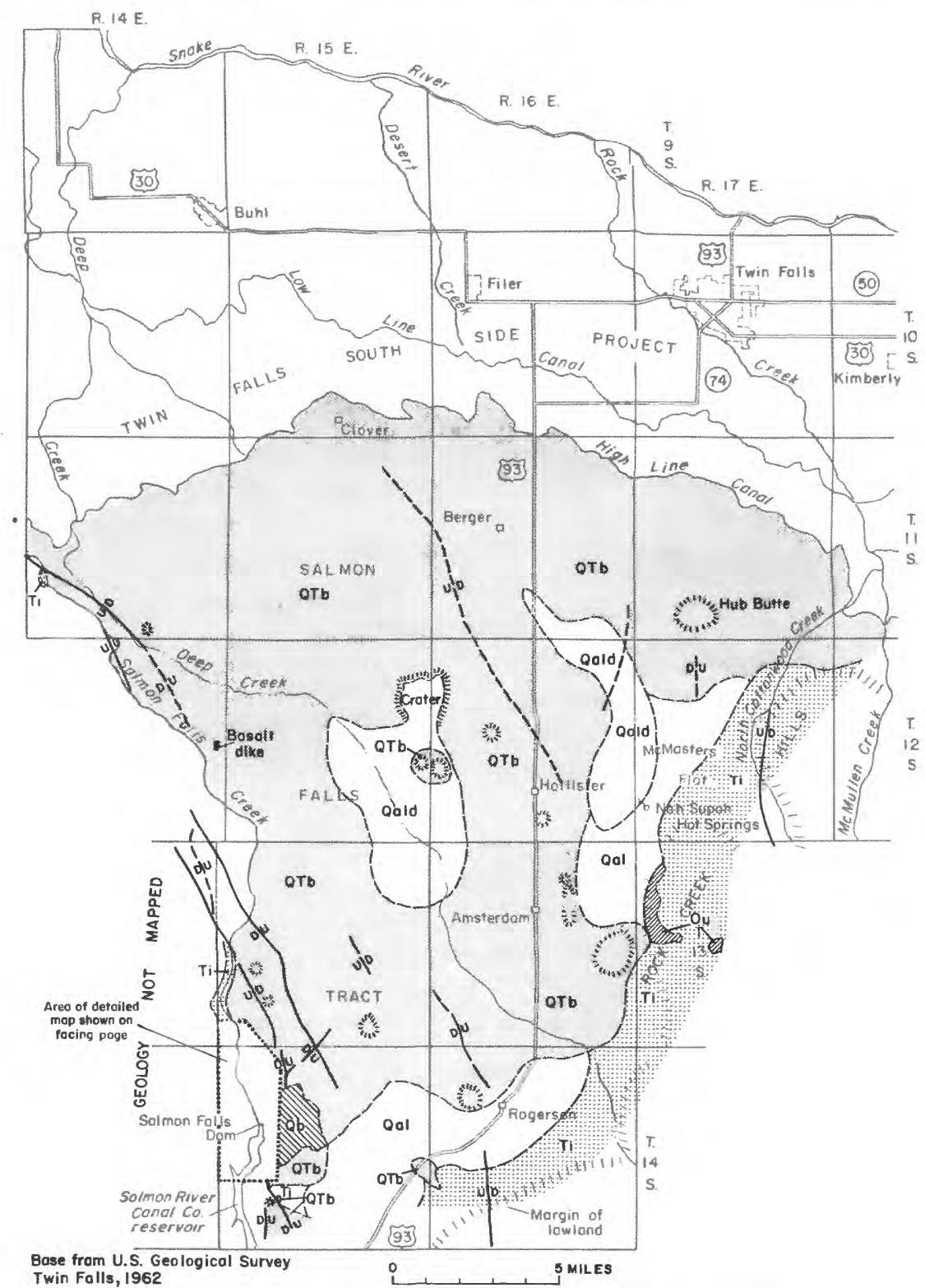

Figure 4. - Geology of the Salmon Falls tract. 


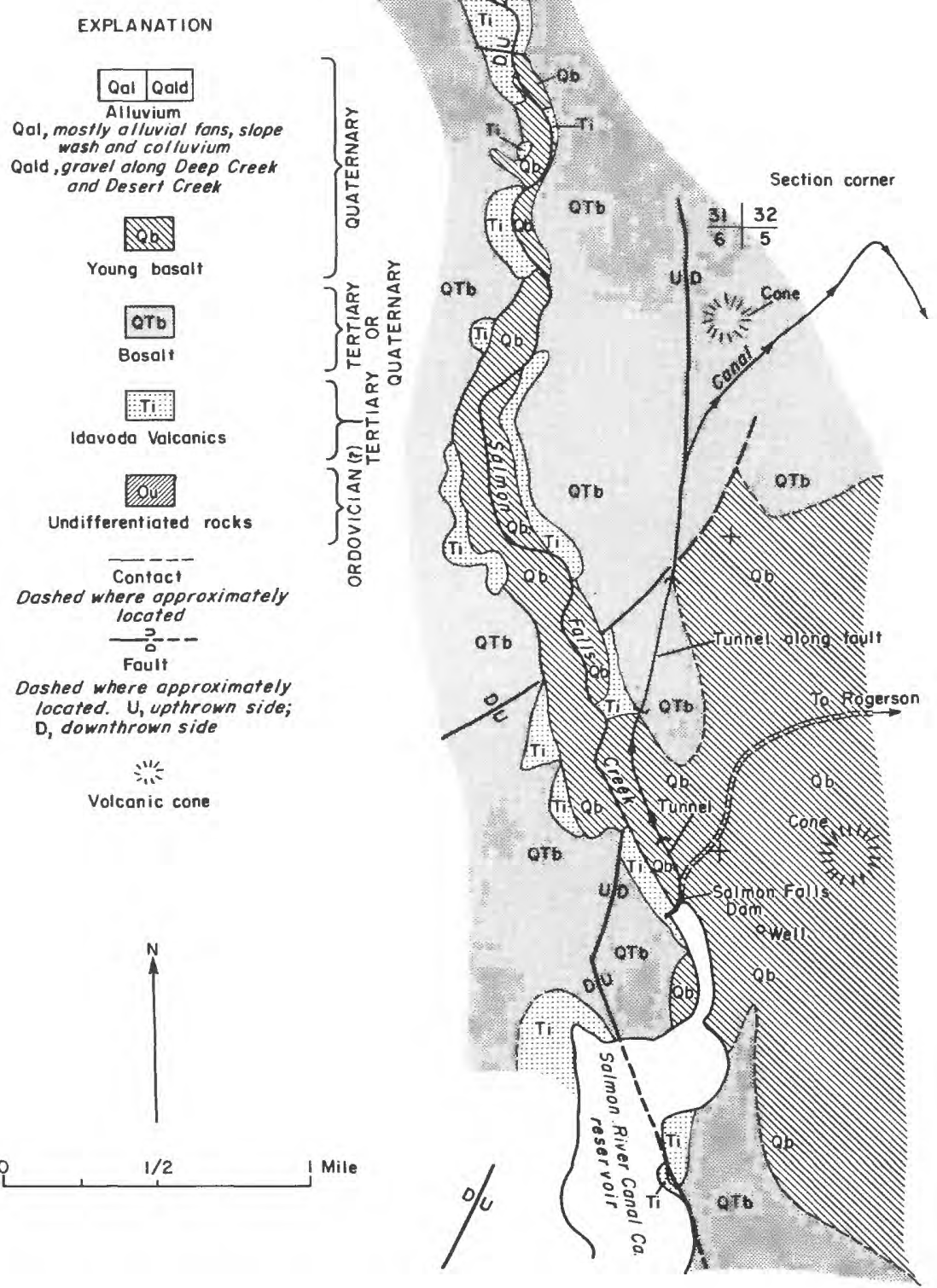


TABLE 1. - Summary of the physical and hydrologic character of rock units in the Salmon Falls tract

\begin{tabular}{|c|c|c|c|c|}
\hline Period & Epoch & Rock unit & $\begin{array}{l}\text { Physical characteristics } \\
\text { and areal distribution }\end{array}$ & Water-bearing character \\
\hline \multirow{3}{*}{ 䔅 } & \multirow{2}{*}{ 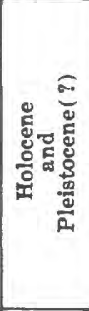 } & $\begin{array}{l}\text { Windblown } \\
\text { deposits } \\
\text { (not shown } \\
\text { in fig. 4) }\end{array}$ & $\begin{array}{l}\text { Clay, silt, and fine sand of } \\
\text { windblown origin blanket } \\
\text { most of the tract. Admixed } \\
\text { with alluvium at some } \\
\text { places. }\end{array}$ & $\begin{array}{l}\text { Contains no ground water } \\
\text { but transmits recharge to } \\
\text { underlying formations. }\end{array}$ \\
\hline & & Alluvium & $\begin{array}{l}\text { Sand and gravel of rhyolitic } \\
\text { composition along Deep } \\
\text { and Desert Creeks. Forms } \\
\text { an apron along the hills } \\
\text { and mountain fronts. }\end{array}$ & $\begin{array}{l}\text { Yields small supplies to } \\
\text { stock wells on south and } \\
\text { east sides of tract. } \\
\text { Contains perched ground } \\
\text { water along Deep Creek. } \\
\text { Yields adequate for small } \\
\text { domestic and stock supplies } \\
\text { during most years. }\end{array}$ \\
\hline & & Young basalt & $\begin{array}{l}\text { Olivine basalt and scoria, } \\
\text { porphyritic, irregularly } \\
\text { jointed ; highly vesicular } \\
\text { and rubbly zones } \\
\text { separating flow units. } \\
\text { Forms cone- and canyon- } \\
\text { filling basalt at Salmon } \\
\text { Falls Dam. }\end{array}$ & $\begin{array}{l}\text { The canyon-filling basalt } \\
\text { should yield large supplies } \\
\text { of water, but is } \\
\text { unimportant because of } \\
\text { limited areal extent. }\end{array}$ \\
\hline \multirow{2}{*}{ 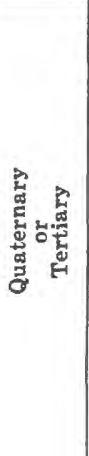 } & 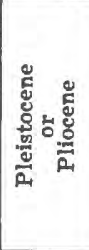 & Basalt & $\begin{array}{l}\text { Olivine basalt flows, light- } \\
\text { to dark-grey, dense to } \\
\text { vesicular, porphyritic, } \\
\text { irregularly jointed; } \\
\text { thickness of flows ranges } \\
\text { from about } 5 \text { to } 75 \text { ft. } \\
\text { Fine-grained lenticular } \\
\text { sedimentary beds as much } \\
\text { as } 15 \text { ft. thick separate } \\
\text { some flows. Underlies } \\
\text { almost all the tract. }\end{array}$ & $\begin{array}{l}\text { Permeability highly variable; } \\
\text { where joints are not filled } \\
\text { with clay and flow contacts } \\
\text { are permeable, yields } \\
\text { moderate or (rarely) large } \\
\text { amounts of water to wells } \\
\text { yields are sufficient for } \\
\text { very small irrigation } \\
\text { supplies at most places. } \\
\text { One of two important } \\
\text { aquifers in area. }\end{array}$ \\
\hline & & $\begin{array}{l}\text { Old lake beds } \\
\text { (not shown } \\
\text { in fig. } 4 \text { ) }\end{array}$ & $\begin{array}{l}\text { Discontinuous beds of clay, } \\
\text { sandy clay, sand, and pea } \\
\text { gravel apparently } \\
\text { occurring in topographic } \\
\text { lows on the Idavada } \\
\text { Volcanics. Reported in } \\
\text { well logs, and appears to } \\
\text { crop out in canyon north } \\
\text { of dam. }\end{array}$ & $\begin{array}{l}\text { The fine-grained sediments } \\
\text { yield little water to wells, } \\
\text { the gravel may yield } \\
\text { moderate quantities of } \\
\text { water. Not an important } \\
\text { aquifer because of limited } \\
\text { areal extent and thickness. }\end{array}$ \\
\hline 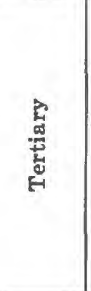 & $\frac{\mathscr{巳}}{\mathscr{E}}$ & $\begin{array}{l}\text { Idavada } \\
\text { Volcanics }\end{array}$ & $\begin{array}{l}\text { Massive, dense, reddish- } \\
\text { brown, gray, and black } \\
\text { silicic volcanic rocks ; } \\
\text { occur as thick flows and } \\
\text { blankets of welded tuff } \\
\text { with associated fine- to } \\
\text { coarse-grained ash and } \\
\text { clay, silt, sand, and gravel. } \\
\text { Underlie all the Salmon } \\
\text { Falls tract, and compose } \\
\text { most of the Rock Creek } \\
\text { Hills and hills south } \\
\text { of the tract. }\end{array}$ & $\begin{array}{l}\text { Permeability highly variable. } \\
\text { Joints and fault zones in } \\
\text { the indurated rocks yield } \\
\text { large quantities of water } \\
\text { at some places, but } \\
\text { massive nonjointed units } \\
\text { yield little water. Sand, } \\
\text { tuff, and ash beds yield } \\
\text { moderate quantities of } \\
\text { water. One of two } \\
\text { important aquifers in the } \\
\text { area. }\end{array}$ \\
\hline 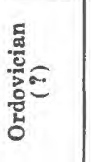 & & $\begin{array}{l}\text { Undifferen- } \\
\text { tiated } \\
\text { rocks }\end{array}$ & $\begin{array}{l}\text { Silicified limestone, silicified } \\
\text { dolomitic limestone, and } \\
\text { quartzite; moderately } \\
\text { jointed with some solution } \\
\text { cavities. Crops out in a } \\
\text { small area at the west edge } \\
\text { of the Rock Creek Hills. }\end{array}$ & $\begin{array}{l}\text { Water moves rather freely } \\
\text { through joints and solution } \\
\text { openings. Potential yield } \\
\text { of formation not known. } \\
\text { Probably not an important } \\
\text { aquifer. }\end{array}$ \\
\hline
\end{tabular}

Most of the consolidated rocks consist of volcanic flows and welded tuffs of late Tertiary and Holocene age. The oldest of these flows and welded tuffs are of silicic composition and are Pliocene in age. They underlie the Salmon Falls tract and are exposed in the hills along the east and south sides of the tract and in the canyon 
of Salmon Falls Creek. Interbedded with the silicic volcanic rocks are beds of ash, clay, and sand. These rocks - the Idavada Volcanics (Malde and Powers, 1962, p. 1200) - probably overlie limestone and quartzite of Paleozoic age. Overlying the Idavada Volcanics at many places are lenticular beds of clay, silt, sand, and gravel with some ash admixed at places.

Basalt of late Pliocene or Pleistocene age overlies the silicic volcanic rocks, sedimentary deposits, and, in some areas, the rocks of Paleozoic age. Overlying the basalt is a veneer of windblown silt and stream alluvium.

\section{GEOLOGIC UNITS IN THE UPPER DRAINAGE BASIN}

No geologic mapping was done in the upper drainage basin, but the reports by Schrader $(1912,1935)$ give a general indication of the distribution of the rock units. Limestone with some quartzite and shale, all of Paleozoic age, granitic rocks of probable Mesozoic age and silicic volcanic rocks and tuffaceous sedimentary denosits of Tertiary age, including the Idavada Volcanics, are the principal rock types. A single basalt flow caps a terrace in the northeast side of the San Jacinto basin. Talus, slopewash, alluvial fans, and stream deposits are widespread throughout the upper drainage basin. Most wells in that area obtain water from tuffaceous sedimentary and silicic volcanic rocks.

\section{STRUCTURE}

All rocks exposed in the lowlands of the Salmon Falls tre $n$ dip northward at about the same rate as the land surface, except where the basalt forms the slopes of domes and vents. Faulting has displaced the Idavada Volcanics and younger formations at several places. A graben (a narrow downdropped block) er'tends north-northwestward in the western part of T. 13 S., R. $15 \mathrm{E}$. (fig. 4). There appears to be another graben north of Ho'lister, but the structure is obscured by windblown deposits.

There are several faults in the vicinity of the Salmon Falls Dam, but none appears to pass through the damsite. The downstream tunnel was driven along a fault that can be traced from a small basaltic cone half a mile north of the tunnel southward across the creek and into the reservoir (fig. 4). Other faulting has occurred in the northwestern part of the area.

The Rock Creek Hills and the hills south of the tract have been considerably faulted. The formations have been broken into hlocks. Although the blocks are tilted in various directions, the predominant dips are to the east, west, and northwest. The limestone of Paleozoic age dips about $30^{\circ}$ E., but the overlying Idavada Volcanics dip only about $5^{\circ} \mathrm{E}$. Nearby, the silicic volcanic rocks dip westward. 
Large-scale normal faulting that formed the Basin and Range structure in Nevada extends into the Salmon Falls C"oek area, and the uplift of the mountain masses in Idaho appears to be related to that orogeny. The east face of Elk Mountain is a fault scarp with a minimum displacement of 1,600 feet. The e $\varepsilon$ st side of the unnamed mountain south of Rogerson appears to be a fault scarp, and a considerable amount of faulting has also occurred along the west side of the Rock Creek Hills.

The faults with large displacement trend north, but most of the smaller faults trend either north or northwest. Small faults associated with the formation of the cone and the emplacement of the basalt flow east of the dam trend in several directions.

The control of ground-water movement by faulting in the Salmon Falls tract is not known. The artesian basin near, and south of, Nah Supah Hot Spring seems to be at least partly the result of faulting which produced a northwest-dipping block of Idavada Volcanics. Basalt squeezed up along some of the faults may have formed dikes filling parts of fracture zones, and these could impede or dam the flow of ground water. At other places fcults may provide avenues for the escape of ground water. Nah Supah Hot Spring and Wildhorse Spring, among others, appear to be fed by water rising along or near faults.

\section{DEVELOPMENT OF WATER RESOURCES}

\section{SURFACE WATER}

Surface water constitutes the largest and most important source of water supply. An average of about 75,000 acre-feet per year was diverted from the reservoir of the Salmon River Canal Co., Ltd., during the period 1938-60; annual diversions ranged from 36,000 acre-feet in 1941 to 105,800 acre-feet in 1943 and 1945. Farm delivery of water ranged from 10,200 acre-feet in 1931 to 85,000 acre-feet in 1922 and averaged about 45,000 acre-feet. The difference between diversions from the reservoir and farm delivery represents losses, including seepage and evaporation, from the canal system. These losses have averaged 40 percent of the water diverted during the 37 years of record (from reports of the Salmon Falls Canal Co., 1912-54 with 6 years of record missing).

Water from the reservoir is also used for stock and domestic purposes. Usually in October, but sometimes as late as November or December, the canal company releases water for these purposes into the canal system to give the farmers an opportunity to store water in ponds and cisterns for use during the winter. The quantity thus diverted ranged from 553 acre-feet in 1952 to 1.268 acre-feet in 1944 and averaged 760 acre-feet for the period 1938-59. 
The runoff of Deep Creek is stored a few miles southwest of Hollister in two small private reservoirs, reported to have a total capacity of 1,400 acre-feet, and the water is used to irrigate a few hundred acres of nearby land. No records are kept of the annual runoff of Deep Creek, but the owner of the reservoirs reported that runoff ranges from a few tens of acre-feet to more than 1,000 acrefeet and that the capacity of the reservoirs has been adequate to control all of it. The reservoirs seldom store water from one year for use the following year.

Two private reservoirs on North Cottonwood Creek have controlled all runoff since they were built. Their owner reported that their total capacity is not more than 1,800 acre-feet and trat he diverts water from McMullen Creek, the next drainage basin east of North Cottonwood Creek, to the lower reservoir. The water is used to irrigate land in the lower valley of North Cottonwood Creek and in the northeastern part of the Salmon Falls tract.

The average annual quantity of surface water diverted from all streams in the Salmon Falls tract does not exceed 80,000 acre-feet.

Water is pumped through a 20 -inch pipeline from Rock Creek to the northeastern part of the tract to irrigate several hundred acres. The pumping plant is in sec. 20, T. 11 S., R. 18 E., and has a reported capacity of 20 cubic feet per second. Continuous pumping during the growing season (120 days) would amount to about 5,000 acre-feet of pumpage.

In the upper drainage basin about 6,500 acres is irrigated by diversion from Salmon Falls Creek and its tributaries. The brlk of the irrigated area is used for production of native hay and for pasture, and a small acreage is devoted to alfalfa, grain, and imr roved hay and pasture (Houston and Naphan, 1952, p. 9 and tal le 4). There are two small private reservoirs on Cow Creek, a trik utary of Trout Creek, which store water for irrigation of a small acreage on the east side of the San Jacinto basin. No records of the diversions are available.

\section{GROUND WATER}

Ground water is used for domestic and stock supplies and, to some extent, for irrigation. The first nonflowing well for which there is a record was drilled in 1909 at the Salmon Falls Dam. The well supplied water to the construction camp and is still used by the gate tender at the dam. During the next 11 years, through 1920 , about 20 nonflowing wells were drilled for domestic and stock use. Development of ground water continued slowly until 1945.

The success of irrigation wells in other parts of Idaho since 1945 stimulated interest in the Salmon Falls tract, and since 1949 about 35 wells have been drilled specifically for irrigation supply 
at locations outside the area of warm artesian water. (See p. D17.) More than half the wells are unused because of inac'oquate yields or high pumping lifts. About 17 wells were used for irrigation during the 1960 farming season, including two wells in the area of warm artesian water. Total annual withdrawals from wells are estimated to be 8,000 acre-feet, of which 2,000 acre-feet was for domestic, stock, and public use.

Yields of irrigation wells in the tract range from about 200 to $1,800 \mathrm{gpm}$ (gallons per minute). Drawdown caused by pumping also ranges widely and exceeds 100 feet in some of the less productive wells. Pumping lifts range from about 100 to 500 feet. In comparing the yields of several wells, yield is conveniently expressed as the specific capacity of a well. Specif capacity is defined as the yield, in gallons per minute per foot of drawdown.

Six of the successful irrigation wells were drilled along the north edge of the Salmon Falls tract within 2 miles of the High Line Canal. Specific capacities of those wells range from 2.5 to 40 gpm per foot of drawdown. The water is used to supplement surface water from the Salmon River Canal Co. reservoir. Three other wells drilled in the vicinity were abandoned because of inadequate yields.

Nine wells have been drilled for irrigation on McMasters Flat. The three existing wells (fig. 5) have specific capacities of 5, 20, and $30 \mathrm{gpm}$ per foot of drawdown; the other six were abandoned because of inadequate yields.

Several miles west and southwest of Hollister, seven wells have been drilled for irrigation, two of which are in use. One yields about $850 \mathrm{gpm}$ and the other about $450 \mathrm{gpm}$ at the start of the irrigation season, but the second one declines to about $250 \mathrm{gpm}$ in the late summer. Some of the ground water is used on land that is also irrigated with water from the Salmon River Canal Co. reservoir and from Deep Creek.

South of Hollister near Amsterdam two irrigation wells yield about $550 \mathrm{gpm}$ each. The water is used to supplement the supply from Salmon River Canal Co. reservoir. There are clso two wells 2 miles east of the Salmon River Canal Co. reservoir that yield about $1,800 \mathrm{gpm}$ each and have specific capacities of about 30 and $70 \mathrm{gpm}$ per foot of drawdown. The water is used to supplement the supply for land served from the Salmon River Canal Co. reservoir and to irrigate about 430 acres above the canal syster of the canal company. In the artesian area southeast of Hollister, two wells were pumped at a combined rate of about $2,500 \mathrm{gpm}$ in 1960 . The water was used to supplement the surface-water supply and to irrigate land without a surface-water supply. 
The first warm-water well of record was reported to have been near the now dry Wild Horse Spring in sec. 36, T. 12 S., R. 16 E., (Russell, 1902). The well was reported to be 75 feet deep and to have yielded a small flow of warm water. According to longtime residents of the area, this well actually was near the present Nah Supah Hot Spring. By 1910 at least three more wells, all flowing, had been drilled in the same general area. Those wells were in sec. 6, T. 13 S., R. 17 E., were 400-760 feet deep, and had a total flow of about $3,000 \mathrm{gpm}$. The water temperature was reported to be $37^{\circ} \mathrm{C}$.

By 1930 about 15 flowing warm-water wells had been drilled southeast of Hollister near the west base of the Rock Creelk Hills. The area of flowing wells is rather sharply defined and includes only about 5 square miles, south and southwestward from Nah Supah Hot Spring (fig. 5). Most of the wells had substantial flows when first drilled, but water levels have declined; now, some wells are unused, and others must be pumped. Reported initial yields ranged from 200 to $1,400 \mathrm{gpm}$. The water is used principally for irrigation and as a municipal supply for Hollister, but some is used for domestic and stock purposes. Water from two wells and from the Nah Supah Hot Spring supplies a commercial swimming pool.

\section{OCCURRENCE OF WATER}

SURFACE WATER

The flow of Salmon Falls Creek is gaged at San Jacinto, Nev., about 10 miles upstream from Salmon River Canal Co. reservoir. Also, the U.S. Geological Survey has made miscellaneous measurements 2 miles below Salmon Falls Dam and at Roseworth Crossing, which permit computation of surface outflow below the dam. Diversions from the reservoir are measured by the canal company, thus permitting computation of the amount lost by evaporation and by seepage to ground water from the reservoir.

North Cottonwood Creek, McMullen Creek, and Deep Creek yield an estimated total of 1,000 acre-feet of surface flow annually to the Salmon Falls tract.

The quantity and disposition of the total surface-water part of the resource is given in table 2.

\section{GROUND WATER}

Ground water in the Salmon Falls Creek basin is derived directly or indirectly from that part of precipitation on the basin that is not transpired by vegetation, is not evaporated from the soil, and does not run off over the land surface out of the basin. The amount that becomes recharge to the ground water depends 
on several factors, among which are the distribution of precipitation in time and space, whether the precipitation oc?urs as rain or as snow, temperature, wind velocity and direction, and amount of sunshine. The rate and amount of recharge are clso affected by the rate of precipitation, and the underlying land-surface material. There is no subsurface inflow of ground water to the Salmon Falls Creek basin, so it is assumed that the total groundwater supply is derived from direct precipitation; percolation from streams, reservoirs, and canals ; and percolation fror excess applied irrigation water.

TABLE 2.-Quantity and disposition of surface water available to the Salmon Falls tract

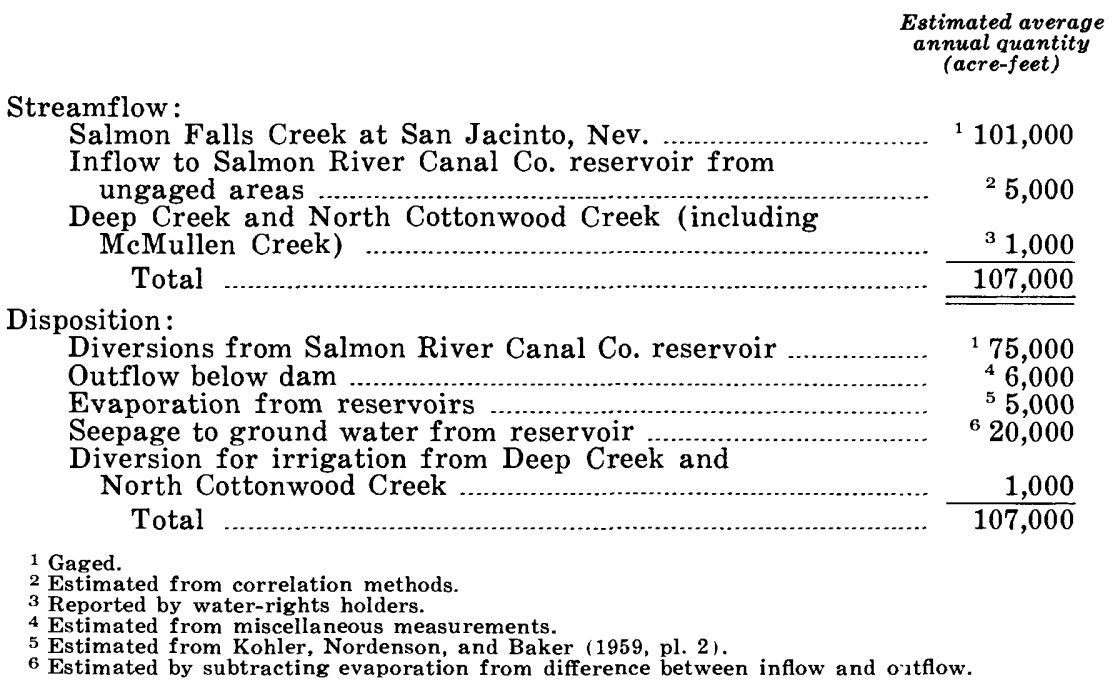

Recharge

The permeability of the geologic units containing and transmitting ground water within the Salmon Falls Creek basin varies as previously noted. Thus, it is virtually impossible to determine the detailed distribution of water recharged to the aquifers without a very large number of observation points adequately distributed over the area. Such data are not available, and only the most general direction of movement of ground water is known. All recharge to ground water within the basin is here assumed to move northward beneath the tract to be pumped for use, or to discharge into the Snake River, or the Snake Plain aquifer.

Few measurements have been made of the quartity of precipitation and streamflow in the Salmon Falls Creel basin, and those few are poorly distributed within the basin and in time. 
Consequently, to estimate the natural water inflow to the hydrologic system of the basin, indirect methods of correlation and extrapolation must be applied to the few data available. A method for estimating total water yield from the drainage areas was developed empirically by Mundorff, Crosthwaite, and Kilburn (1964, p. 43-46 and fig. 7) and was revised by Mundorff, Broom, and Kilburn (1963, p. Q37-Q38 and fig. 8). As reported in the above publications, several small basins tributary to the Snake River Plain were such that all natural outflow from the basin could be measured as streamflow. Total annual precipitation over the basin could be estimated from precipitation maps of the basins. From these data a curve was constructed which defined the empirical relationship of precipitation to water yield from the basin. Water yield, as thus used, is all water leaving the basin by surface or underground flow. The curve provides a means of estimating the average annual water yield in geographically comparable areas wherever a reasonable estimate of total annual precipitation is available.

The geographic, climatic, and general hydrologic corditions in the Salmon Falls Creek basin appear to be similar to those in basins used to develop the water yield-precipitation relaticnships. Therefore, the relationship is assumed to be applicable to the basin, and the curve is used in this report. Using this curve and the precipitation map (fig. 2), the estimated total annual water yield of the entire Salmon Falls Creek basin is 320,000 acre-feet.

To derive an estimate of the ground-water recharge in the Salmon Falls Creek basin, the water yield for the various subbasins and drainage units was calculated by deriving precipitation estimates from the precipitation map of figure 2 and subtracting surface outflow. Where surface outflow from a subbasin is gaged, the measured outflow was compared with the water-yield estimate from the curve, and the difference was considered to be groundwater recharge. Where surface outflow was not gaged, streamflow was estimated. The average annual ground-water recharge due to precipitation is estimated by this method to be 214,000 acre-feet.

The precipitation-water yield relationship for the area above the surface-water gage near San Jacinto (fig. 2) suggests that about 295,000 acre-feet should drain from the area annually. The measured surface outflow is 101,000 acre-feet, so about 194,000 acre-feet of subsurface outflow presumably moves northvard as ground-water recharge. By similar reasoning the ungaged area tributary to the Salmon River Canal Co. reservoir (fig. 2) should yield about 10,000 acre-feet annually. One-half, or 5,000 acre-feet, 
of this yield is estimated to join the reservoir as surface flow. Consequently, about 5,000 acre-feet of ground-water recharge is estimated to be contributed annually from the ungaged area.

There is no surface runoff from the area of the Salmon Falls tract, so the water yield (using the precipitation-water-yield relationship) from this area is considered to be total ground-water recharge. This is estimated to be 15,000 acre-feet annually.

Another means of estimating ground-water recharge was developed by Eakin and others (1951) in which average precipitation ranges were assigned to altitude zones and delineated on a map. In an attempt to better define the method, Moore and Eakin (1968) recently used a systems-analysis approach to estimate the hydrologic budget of the Snake River drainage in Nevada. Moore and Eakin's method was applied to the same subbesins as used previously in this report. The estimated ground-water recharge above the gage near San Jacinto is computed to be 45,000 acre-feet annually. In the ungaged area ground-water recharge is estimated to be 4,000 acre-feet annually, and in the Salmon Falls tract it is estimated to be 1,000 acre-feet annually.

Table 3 gives the increments of ground-water recharge from precipitation on the tributary drainage areas estimated by the two methods along with contributions from percolatior of seepage from the reservoirs and canals and from excess applied irrigation water.

TABLE 3. - Estimated ground-water recharge to the Salmon Falls tract

\begin{tabular}{|c|c|c|}
\hline & \multicolumn{2}{|c|}{$\begin{array}{c}\text { Estimated average annual recharge } \\
\text { (acre.ft) }\end{array}$} \\
\hline & $\begin{array}{c}\text { From method of } \\
\text { Mundorff, Broom, } \\
\text { and Kilburn (1963) }\end{array}$ & $\begin{array}{c}\text { From method of } \\
\text { Moore and Eakin } \\
(1968)\end{array}$ \\
\hline Gaged area (precipitation) & 194,000 & 45,000 \\
\hline Ungaged area (precipitation) & 5,000 & 4,000 \\
\hline Salmon Falls tract (precipitation) & 15,000 & 1,000 \\
\hline Seepage to ground water from Salmon River & & \\
\hline 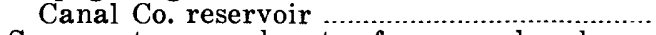 & 20,000 & 20,000 \\
\hline $\begin{array}{l}\text { Seepage to ground water from canal and } \\
\text { lateral system }\end{array}$ & 30,000 & , \\
\hline Deep percolation from irrigated fields & 15,000 & 15,000 \\
\hline Total & 279,000 & 115,000 \\
\hline
\end{tabular}

Obviously, the results of the two methods of estimating groundwater recharge do not agree probably because of the inadequacy of the available data. Until more precise data and analytical methods are available, the smaller quantities are suggested to be provisionally accepted as an approximate magnitude of groundwater recharge derived from direct precipitation on the drainage basin. 
The total annual inflow to Salmon River Canal Co. reservoir averages about 106,000 acre-feet. An average of 75,000 acre-feet is diverted each year for irrigation in the Salmon Falls tract. Of the rest, about 6,000 acre-feet is estimated to leak from the reservoir and flow out of the area as surface flow in Salmon Falls Creek downstream from the dam. Evaporation from the approximately 1,500 acres of reservoir surface is about 38 inches annually, which suggests that about 5,000 acre-feet of water is lost by evaporation each year. The remaining 20,000 acre-feet is estimated to percolate to ground water.

Seventy-five thousand acre-feet of water is diverted annually into the approximately 300 miles of the Salmon River Canal Co. canals and laterals, but an average of only about 45,000 acre-feet is delivered to the fields. The average annual diversion of 760 acre-feet for stock and domestic use is ignored. Numerous studies of seepage losses from the canals and laterals have shown considerable variations between canals from time to time, but the studies adequately support an average loss of about 30,000 acrefeet annually. This quantity is assumed to percolate directly to ground water.

Regardless of the care with which water is applied for irrigation, a part of the average annual application of 45,000 acre-feet escapes evapotranspiration and percolates to ground water. Consumptive use by the irrigated crops of the Salmon Falls tract averages about 1.5 acre-feet per acre (p. D8), and an estimated average of about 20,000 acres is irrigated annually. Thus, about 30,000 acre-feet is evaporated or transpired, and about 15,000 acre-feet percolates to ground water.

\section{The Water Table}

The water table beneath the Salmon Falls tract is in near balance between recharge and discharge. Spring runoff and excess water applied for irrigation cause the water table to rise and reach a peak in the late summer. Thereafter, the water table declines until the next runoff season. The known magnitude of the yearly fluctuations ranges from 12 feet at the north end of the tract to only 2 feet southeast of Hollister.

Although withdrawals by irrigation wells cause a large lowering of the water table in the immediate vicinity of the wells, the effect is not large regionally because pumpage is small in comparison with the quantity of ground water in storage.

The general slope of the water table is to the northwest (fig. 5). The slope is modified locally near the sources of recharge or discharge and by large changes in permeability or thickness of the water-bearing formations. 


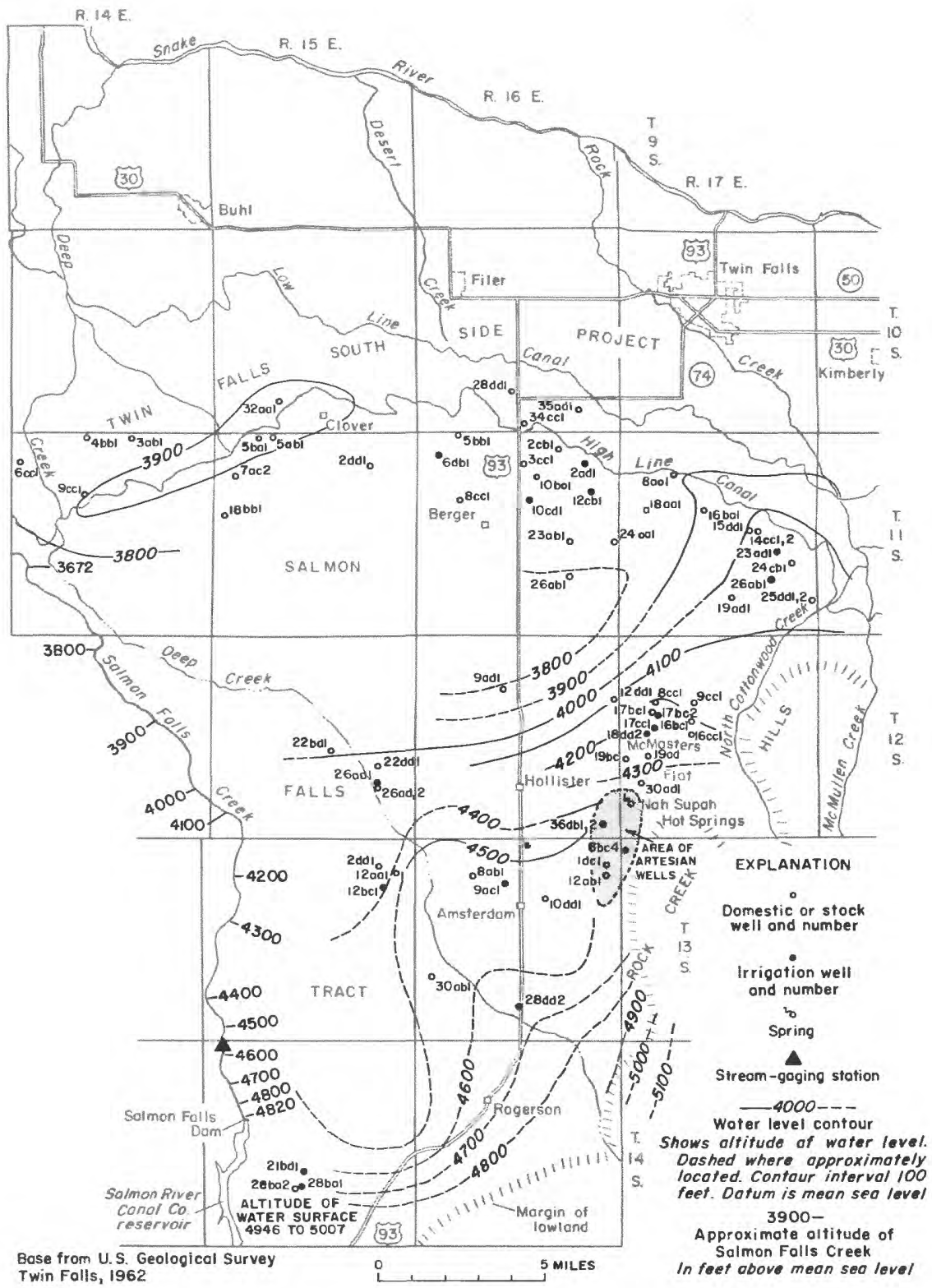

Figure 5. - Well locations and water-level contours.

The most obvious local change in the generally northwesterly slope of the water table is caused by recharge from leakage from the High Line Canal and by recharge from irrigation north of the Salmon Falls tract (fig. 5). The canal carried water almost con- 
tinuously from 1909 to 1961 , after which winter diversions were reduced or discontinued. Seepage from the canal and percclation from 202,000 acres of irrigated land in the Twin Falls South Side Project have raised the water table beneath the project many feet. Stearns, Crandall, and Steward $(1938$, p. 179) reported that the water table rose more than 200 feet at some places between 1906 and 1928. The rise of water level beneath the Twin Falls South Side Project built up a ground-water ridge on the northwestwardsloping water table. The water from the ridge spread southward and caused a rise of the water table beneath the northern part of the Salmon Falls tract. Remeasurement during the present study of some wells measured by Stearns, Crandall, and Steward (1938) in 1928 and measurements made by the Twin Falls Canal Co. between 1931 and 1944 showed no significant changes in water levels just north of the High Line Canal since 1928. However, any significant changes in the amount of water diverted to the Twin Falls South Side Project area will change the amount of recharge to, and influence water levels beneath, the northern part of the Salmon Falls tract.

In the northwest corner of the Salmon Falls tract, seepage loss from the High Line Canal of the Twin Falls South Side Project has also built up a mound on the water table (fig. 5). The position of the south slope of the mound is poorly known because we'ls are sparse in that part of the area, but it seems likely that ground water moves from the mound southwestward to Salmon Falls Creek.

The large bulge or low ridge on the water table southwest of Hollister (fig. 5) is caused by downward percolation of the perched water in the Deep Creek drainage supplemented by canal losses and percolation from irrigated fields. There are three producing irrigation wells in the area of gentle water-table gradient, but their yields are modest, and drillers' logs show considerable clay in the interval between 300 and 400 feet below land surface. Thus, the contours in that part of the tract may represent a perched water table instead of the main water table.

No attempt was made to construct contours on the piezometric surface in the artesian area southeast of Hollister. The artesian head is at an altitude of about 4,650 feet in sec. 6 , T. 13 S., R. 17 E., but is several feet lower to the north and northwest. Artesian conditions are present locally, as in T. 11 S., R. 17 E., which further complicates attempts to depict the true ground-water surface.

In general, the depth to water ranges from 100 to 400 feet below land surface northeastward from Amsterdam to the High Line Canal and in a strip 1-3 miles wide along the south side of 
the High Line Canal. Depth to water beneath some of the larger buttes in the area is as much as 850 feet.

\section{Discharge}

The natural discharge of ground water beneatr the Salmon Falls tract is by underflow northward into the Snake River and Rock Creek. A small amount discharges into Salmor. Falls Creek. The annual ground-water discharge from the tract is equal to the recharge plus or minus changes in storage. The arnual groundwater recharge is provisionally estimated to be 115,000 acre-feet (p. D19-D21). Ground-water withdrawals through vells were estimated to have been 8,000 acre-feet in 1960. Comparison of waterlevel measurements made in 1956-57 with measurements made in 1960-61 does not indicate any significant changes in ground-water levels, except locally near some of the irrigation wells. Changes in storage, therefore, were apparently small.

In the artesian area southeast of Hollister, some wells have stopped flowing, and the yields of the wells that supply the village of Hollister have declined progressively since the wells were drilled, which suggests that artesian pressures are declining.

\section{RESULTS OF TEST DRILLING}

As an aid to this study, the Bureau of Reclamation in 1960-61 drilled seven observation wells to measure water lovels and to obtain geologic information at widely separated locations in the tract. The wells were drilled in parts of the tract where it was thought the best geologic and hydrologic information would be gained for interpreting the potential yield of the vater-bearing formation. Table 4 summarizes information about the wells drilled, and figure 6 shows the generalized lithologic $\log _{\mathrm{s}}$ of the wells. None of the test wells (table 4 ) had a yield suitable for an irrigation supply.

TABLE 4. - Test and observation wells drilled in the Salmon Falls tract

\begin{tabular}{|c|c|c|c|c|c|}
\hline Well No. & $\underset{\text { (ft) }}{\text { Depth }}$ & $\begin{array}{l}\text { Diam- } \\
\text { eter } \\
\text { (in.) }\end{array}$ & $\begin{array}{l}\text { Depth to } \\
\text { water } \\
\text { (feet } \\
\text { below } \\
\text { land } \\
\text { surface) }\end{array}$ & Purpose & Remarks \\
\hline $11 \mathrm{~S}-15 \mathrm{E}-7 \mathrm{ac} 2 \ldots$. & 347 & $8-6$ & 225 & \multirow{2}{*}{$\begin{array}{l}\text { Observation well and } \\
\text { geologic data: } \\
\text { To determine yield }\end{array}$} & \multirow{7}{*}{$\begin{array}{l}\text { Well might yield } 10 \mathrm{gpm} \text {. } \\
\text { Yields about } 50 \text { gpm with } \\
150 \mathrm{ft} \text { of drawdown. } \\
\text { Probal y would yield } 100 \\
\text { gpm. } \\
\text { Yield not tested, but } \\
\text { prob?bly adequate for } \\
\text { stock purposes. } \\
\text { Yield } 280 \text { gpm with } 140 \\
\text { ft of drawdown. } \\
\text { Might yield } 10 \mathrm{gpm} \text {. }\end{array}$} \\
\hline $11 \mathrm{~S}-17 \mathrm{E}-25 \mathrm{dd} 1 \ldots$ & 348 & 20 & 92 & & \\
\hline $11 \mathrm{~S}-17 \mathrm{E}-25 \mathrm{dd} 2 \ldots$ & 352 & 8 & 88 & $\begin{array}{l}\text { Observation well and } \\
\text { geologic data. }\end{array}$ & \\
\hline $12 \mathrm{~S}-15 \mathrm{E}-22 \mathrm{bd} 1 \ldots$ & 638 & $8-6$ & 512 & $\begin{array}{l}\text { Position of water table } \\
\text { and geologic data. }\end{array}$ & \\
\hline $13 \mathrm{~S}-16 \mathrm{E}-10 \mathrm{dd} 1 \ldots$ & 775 & $20-16-12$ & 80 & \multirow{3}{*}{$\begin{array}{l}\text { Geologic information } \\
\text { and yield data. } \\
\text { Position of water table } \\
\text { and geologic data. } \\
\text { Observation well and } \\
\text { geologic data. }\end{array}$} & \\
\hline $13 \mathrm{~S}-16 \mathrm{E}-30 \mathrm{ab} 1 \ldots$ & 340 & $8-6$ & 114 & & \\
\hline $14 \mathrm{~S}-15 \mathrm{E}-28 \mathrm{ba} 2 \ldots$ & 455 & $8-6$ & 95 & & \\
\hline
\end{tabular}



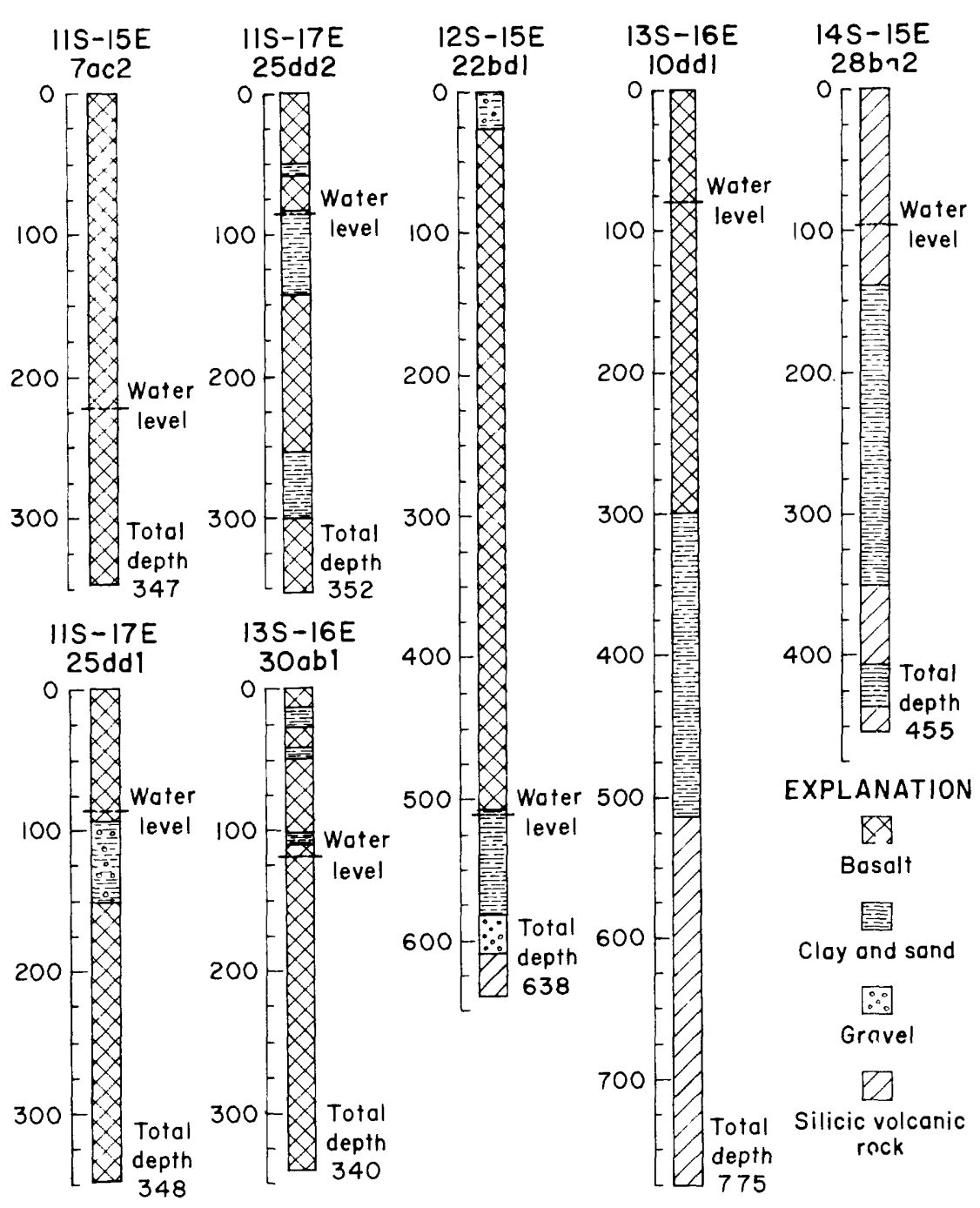

FIGURE 6. - Generalized lithologic logs of observation wells drilled for this investigation.

Well 13S-16E-10dd1 was pumped twice to sample two possible water-bearing formations. This was done by seating the unperforated casing in clay at about 525 feet and testing the uncased silicic volcanic rocks from 525 to 775 feet. Next, the casing was perforated, and the well was pumped again. The specific capacity was about 0.6 after pumping 1.5 hours in the silicic volcanic rocks and was 2 for the entire well after pumping 11 hours. The basalt and sediments thus yielded about $1.4 \mathrm{gpm}$ per foot of drawdown. This well illustrates the hazard involved in exploring for ground 
water in the Salmon Falls tract. The well bore penetrated 220 feet of water-saturated basalt, 215 feet of saturated sediments, and 260 feet of saturated silicic volcanic rocks for a total of 695 feet of hole below the water table. Yet the well did not intercept enough crevices in the volcanic rock or enough coarse-grained sediments to yield sufficient water for an irrigation supply under present economic conditions.

Comparison of the yields of wells $14 \mathrm{~S}-15 \mathrm{E}-28 \mathrm{ba} 1$ and $13 \mathrm{~S}-$ $16 \mathrm{E}-10 \mathrm{dd} 1$ illustrates the wide range in yield of the silicic volcanic rocks. The former of the two wells has a specific capacity of about 40 compared with 0.6 in well $13 \mathrm{~S}-16 \mathrm{E}-10 \mathrm{dd} 1$.

\section{QUALITY OF WATER}

Water moving through or over geologic materials dissolves some of the products of rock weathering, and the chemical content thus gained affects the usability of the water. For example, excessive concentrations of calcium and magnesium cause hardness in water and make it objectionable for domestic use.

Results of 20 analyses of ground water from wells in the Salmon Falls tract are given in table 5. Results of 26 other analyses of ground water were given in a report by Fowler (1960, p. 14-15).

The U.S. Geological Survey reports water temperature in degrees Celsius (Centigrade). The following table is provided to give the reader a convenient means of converting derrees Celsius to degrees Fahrenheit.

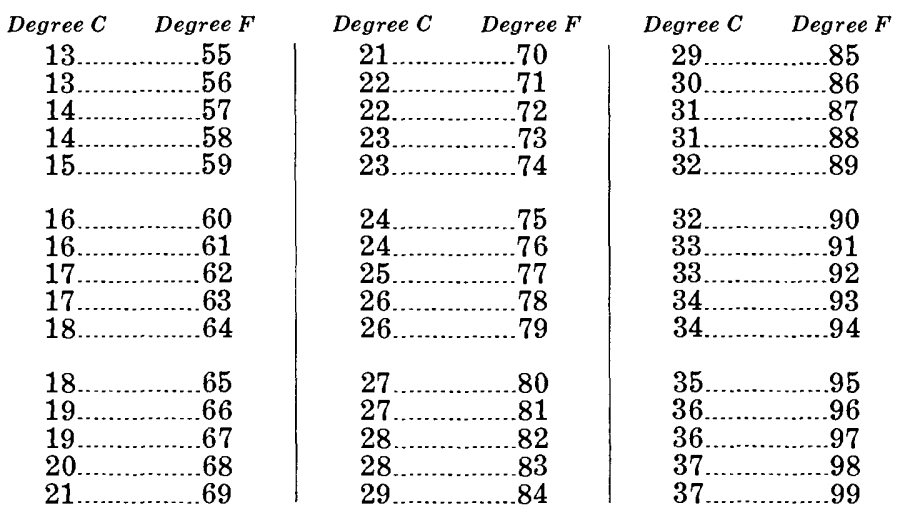

SUITABILITY OF GROUND WATER FOR IRRIGATION

The concentration and relative ratios of several chemical constituents are used in evaluating the suitability of the water for irrigation. These constituents include the total concentration of soluble salts, the concentration of individual constituents (notably boron and sodium) and the relative proportions of sodium 


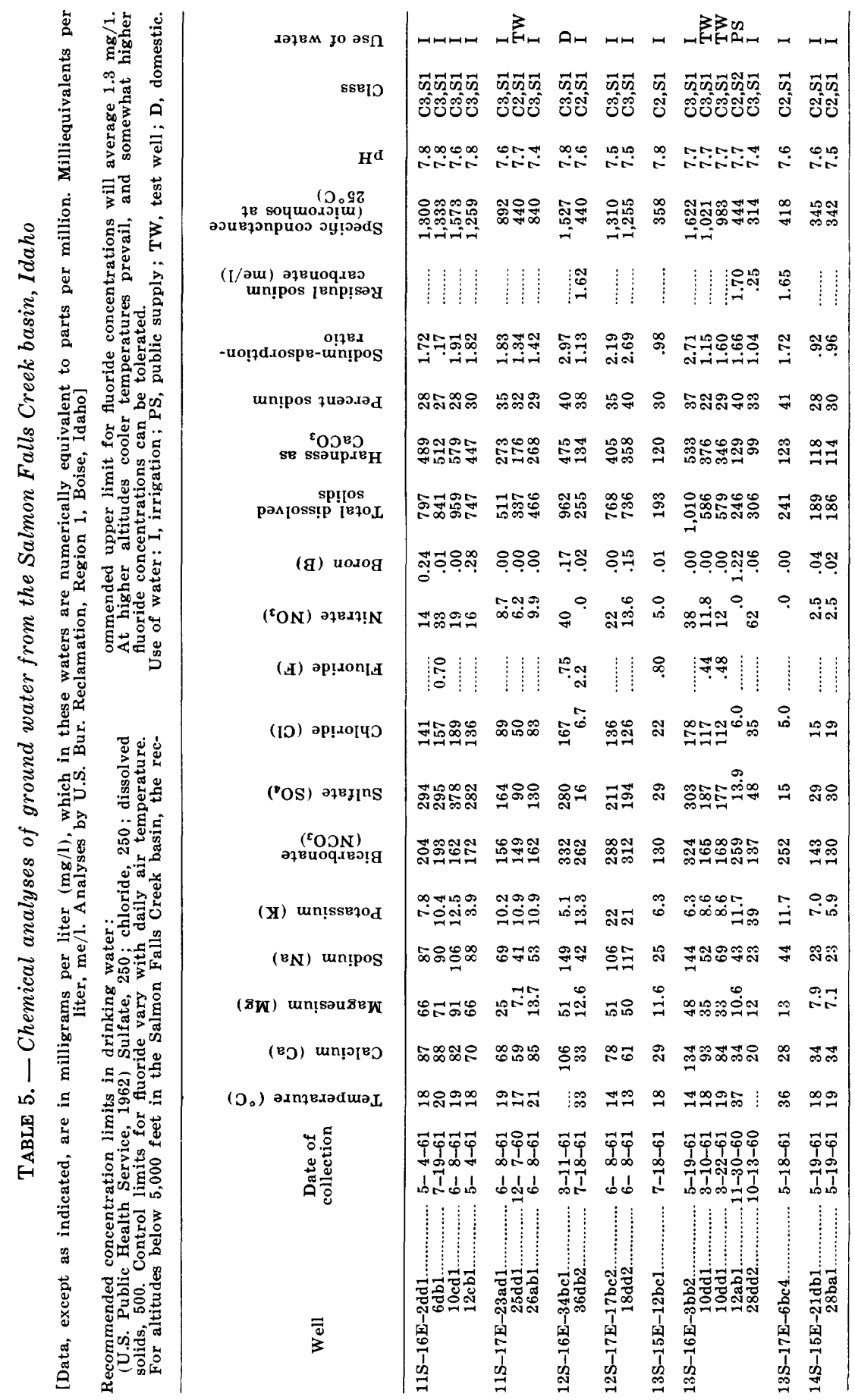




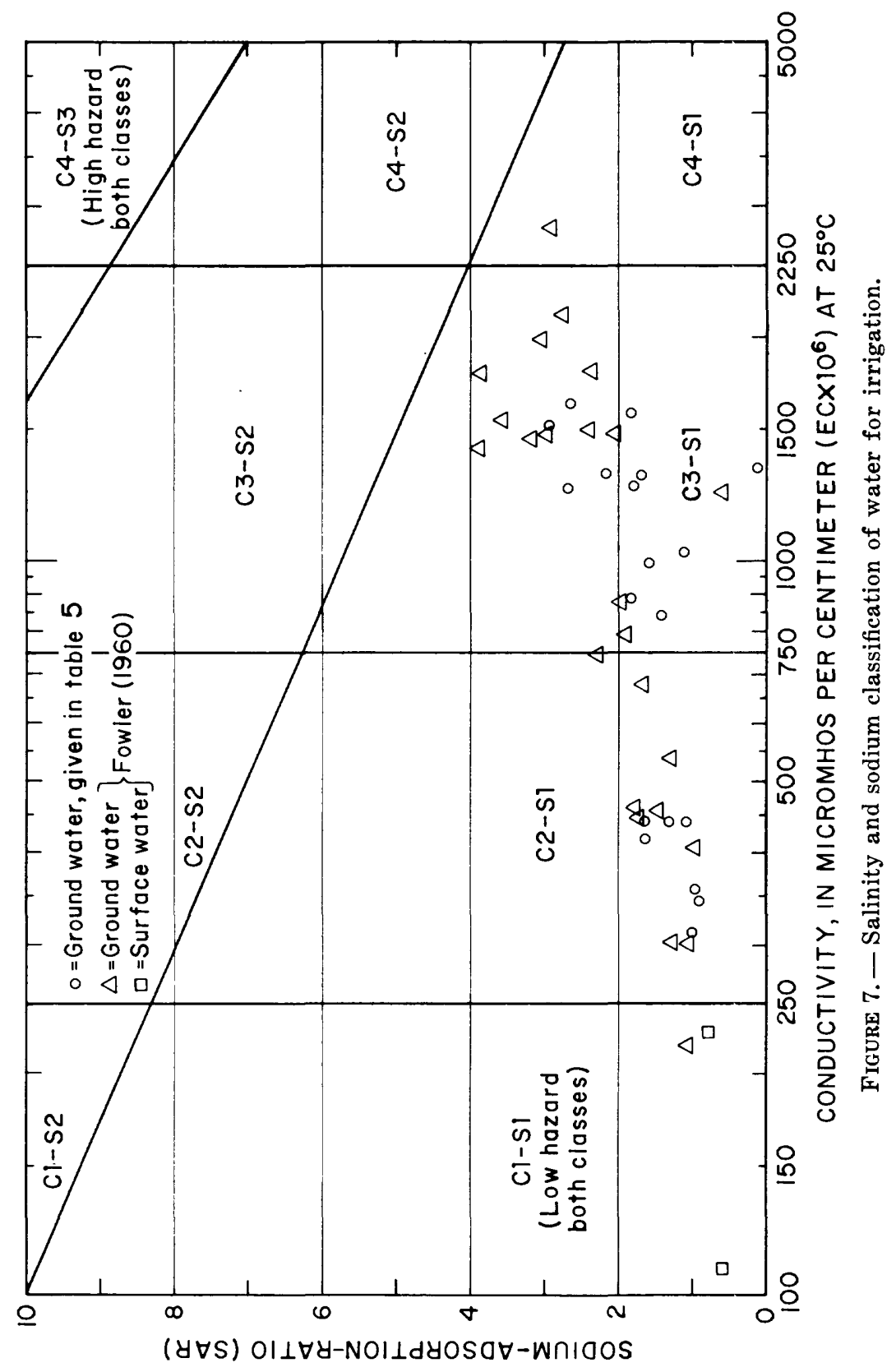


to other cations. Under some conditions the bicarbonate concentration, as related to the concentrations of calcium and magnesium, affects the utility of water for irrigation. However, the successful use of a particular water may depend on other factors, such as the chemical composition of the soil, type of crops grown, methods of cultivation, and fertilization of the soil.

Several methods are used to classify water as to its suitability for irrigation.

One method of classification uses "residual sodium carbonate" as an indicator of suitability of a water for irrigation (U.S. Salinity Laboratory Staff, 1954, p. $75-76,81)$. This is defined by the equation: $\mathrm{RSC}=\left(\mathrm{CO}_{3}{ }^{-2}+\mathrm{HCO}_{3}{ }^{-1}\right)-\left(\mathrm{Ca}^{+2}+\mathrm{Mg}^{+2}\right)$,

where the concentration of ions is expressed in me/l (millieruivalents per liter). ${ }^{1}$ Waters containing more than $2.5 \mathrm{me} / 1$ residual sodium carbonate are not considered safe for irrigation; those containing $1.25-2.5 \mathrm{me} / \mathrm{l}$ are considered marginal ; and those containing less than $1.25 \mathrm{me} / \mathrm{l}$ are probably safe. Three samples given in table 5 are marginal according to this classification.

Another method of determining the sodium hazard involves the computation of the sodium-adsorption-ratio (SAR), and is determined by the following relation where the ion concentration is expressed in me/1:

$$
\mathrm{SAR}=\frac{\mathrm{Na}^{+1}}{\sqrt{\mathrm{Ca}^{+2}+\mathrm{Mg}^{+2} / 2}} .
$$

The sodium hazard as defined by the SAR is divided into four classes, S1-S4, S1 indicating a water having a low sodium hazard, and $\mathrm{S} 4$, a water having a high sodium hazard. The divisions between the classes are delimited by empirical equations and plot as straight lines on semilogarithmic paper (fig. 7). This plot compares SAR and specific conductance of the water samples, the specific conductance being a rough measure of total-discolvedsolids content of the water, or of its "salinity," in terms of a classification commonly used (U.S. Salinity Laboratory Staff, 1954).

The four salinity classes, based on specific conductance, are:

C1. Less than 250 micromhos, low salinity hazard.

C2. 250-750 micromhos, medium salinity hazard.

C3. 750-2,250 micromhos, high salinity hazard.

C4. More than 2,250 micromhos, very high salinity hazard.

Data shown in figure 7 indicate that all samples from the Salmon Falls tract had a low sodium hazard. Water from Salmon

\footnotetext{
1 Millieguivalents per liter is the milligrams per liter of a dissolved ion divided by the gramequivalent weight of the ion.
} 
River Canal Co. reservoir is highly satisfactory for irrigation because the salinity hazard is low. Among the ground-water samples, 17 were of medium salinity, 25 were of higl salinity, and one showed very high salinity; however, the water $r$ ?presented by this last sample is not used for irrigation. As most of the soil in the area is readily permeable, and because well water and surface water are mixed or are used alternately for irrigation, saline-soil problems have not arisen in the area. Conditions are present, however, that make soil-salinity problems possible in the future, and good irrigation practices should be followed to reduce this risk.

Relative tolerance to salinity of some crop plants generally grown in the Salmon Falls tract is as follows:

\begin{tabular}{|c|c|c|c|}
\hline Sensitive & Mode & ly tolerant & Tolerant \\
\hline Field beans & Peas & Alfalfa & Sugar beets \\
\hline Red clover & Onions & Yellow sweet clover & Barley \\
\hline & Potatoes & White sweet clover & \\
\hline & Sweet corn & Oats & \\
\hline & Field corn & Wheat & \\
\hline & Smooth brome & Rye & \\
\hline & Orchard grass & & \\
\hline
\end{tabular}

Boron is essential to plant growth, but a small excess is toxic to some plants. Hem (1959, p. 244-246) discussed the effects of boron and a classification for irrigation use. The classification is not repeated here because, with the exception of well $13 \mathrm{~S}-16 \mathrm{E}-$ 12ab1, the concentration of boron in waters sampled would have little effect on plants commonly grown in the tract. Well $13 \mathrm{~S}-16 \mathrm{E}-$ $12 \mathrm{ab} 1$ is used principally for a public supply.

\section{SUITABILITY OF GROUND WATER FOR DOMESTIC PURPOSES}

The U.S. Public Health Service drinking-water standards are given in table 5 for comparison with the chemical constituents determined for 20 water samples. The Public Healtr Service also has standards for additional constituents not determined in these analyses. Water used in the home should be free from color and turbidity and should have no unpleasant odor or taste; also, it should be safe from bacteria or other harmful organisms. In general, ground water in the Salmon Falls Creek basin is believed to meet the recommended criteria for turbidity, odor, taste, color, and micro-organisms.

Most people can detect a salty taste if the chloride content is above 200-300 mg/l (milligrams per liter); howєver, chloride contents somewhat higher than this may not be objectionable. Fowler (1960) reported two waters that had chloride concentrations in excess of $250 \mathrm{mg} / \mathrm{l}$. Most sulfate salts have a laxative effect on some people. Fourteen samples, including eight from 
Fowler (1960), had more than $250 \mathrm{mg} / \mathrm{l}$ sulfate. Fluoride content in water of about $1.5 \mathrm{mg} / \mathrm{l}$ can, depending on the average annual temperature, cause mottling of children's teeth. Two samples, including one from Fowler (1960), had more than $1.5 \mathrm{mg} / \mathrm{l}$. One sample was taken from a well used for irrigation, and the other, from a well used to supply a swimming pool. Excessively high nitrate content may indicate contamination of the water from organic materials, or it may be the result of natural concitions. Nitrate content in water greater than about $44 \mathrm{mg} / \mathrm{l}$ appears to cause cyanosis, or "blue baby" disease, in infants. Fowler (1960) found five samples of water that contained more than $44 \mathrm{mg} / \mathrm{l}$ nitrate.

\section{SUMMARY OF WATER QUALITY}

The analyses indicate that the basalt and old lake beds yield water of fair to good quality for both irrigation and domestic use. Nonetheless, the ground water from those sources is hardor and has higher concentrations of magnesium, sulfate, nitrate, chloride, and total dissolved solids than water from the Idavada Volsanics. In general, water from the Idavada Volcanics has a lower salinity hazard than water from other formations and is therefore chemically more desirable for both domestic and irrigation supplies. Almost none of the water seems to have a potential sodium razard.

\section{CONCLUSIONS}

The present surface-water supply of 107,000 acre-feet is fully utilized, and the only way to increase the effectiveness cf that supply would be to reduce seepage losses by lining large parts of the 100 miles of main canals and the 200 miles of laterals and ditches in the distribution system of the Salmon River Caral Co., Ltd. A limited amount of ground water is available for irrigation south of Hollister, southwest of Rogerson, in McMasters Flats, south of the High Line Canal of the Twin Falls Canal Co., and in the area of artesian ground water southeast of Hollister. In general, the permeability of the water-bearing formations is low, and the depth to water is not favorable in parts of the area. The provisionally estimated average annual ground-water recharge is 115,000 acre-feet to the Salmon Falls tract. About 8,00 acrefeet was pumped in 1960 for irrigation, domestic, and stork use.

The chemical quality of the water in the Idavada Volcanics will remain good, and the quality in the other formations will remain satisfactory, if saline residuals are not allowed to accumulate. 


\section{REFERENCES}

Blaney, H. F., and Criddle, W. D., 1949, Consumptive use of water in the irrigated areas of the upper Colorado River Basin: U.S. Dent. Agriculture, Soil Conserv. Service, $49 \mathrm{p}$.

Eakin, T. E., Maxey, G. B., Robinson, G. W., Fredericks, J. C., and Loeltz, O. J., 1951, Contributions to the hydrology of eastern Nevada: Nevada State Engineer, Water Resources Bull. 12, 171 p.

Fowler, K. H., 1960, Preliminary report on ground water in tl 9 Salmon Falls area, Twin Falls County, Idaho: U.S. Geol. Survey Circ. 436, 17 p. [1961].

Hem, J. D., 1959, Study and interpretation of the chemical characteristics of natural water: U.S. Geol. Survey Water-Supply Paper 1473, 269 p.

Houston, C. E., and Naphan, E. A., 1952, Consumptive use of water in irrigable areas of the Columbia River basin in Nevada: U.S. Dept. Agriculture Soil Conserv. Service, $35 \mathrm{p}$.

Jensen, M. C., and Criddle, W. D., 1952, Estimated irrigation water requirement for Idaho: Idaho Univ. Agr. Expt. Sta. Bull. 291, 23 p.

Kohler, M. A., Nordenson, T. J., and Baker, D. R., 1959, Evaporation maps for the United States: U.S. Weather Bur. Tech. Paper 37, 13 p.

Malde, H. E., and Powers, H. A., 1962, Upper Cenozoic stratigraphy of Western Snake River Plain, Idaho: Geol. Soc. America Bull., v. 73, no. 10, p. 1197-1220.

Moore, D. O., and Eakin, T. E., 1968, Water-resource appraisal of the Snake River basin in Nevada: Nevada Dept. Conserv. and Nat. Resources Water Resources - Reconn. Ser. Rept. 48.

Mundorff, M. J., Broom, H. C., and Kilburn, Chabot, 1963, Reconnaissance of the hydrology of the Little Lost River basin, Idaho: U.S. Geol. Survey Water-Supply Paper 1539-Q, 51 p.

Mundorff, M. J., Crosthwaite, E. G., and Kilburn, Chabot, 1964, Ground water for irrigation in the Snake River basin in Idaho: U.S. Geol. Survey Water-Supply Paper 1654, 224 p.

Robinson, A. E., 1913, Ninth biennial report of the State Engineer of Idaho: Boise, Idaho, p. 302-309.

Russell, I. C., 1902, Geology and water resources of the Snale River Plains of Idaho: U.S. Geol. Survey Bull. 199, 192 p.

Schrader, F. C., 1912, A reconnaissance of the Jarbidge, Contact, and Elk Mountain mining districts, Elko County, Nevada: U.S. Geol. Survey Bull. 497, $162 \mathrm{p}$.

1935, The Contact mining district, Nevada: U.S. Geol. Survey Bull. 847-A, p. 1-41.

Simons, W. D., 1953, Irrigation and streamflow depletion in Columbia River basin above The Dalles, Oregon: U.S. Geol. Survey Water-Supply Paper 1220, 126 p. [1954].

Stearns, H. T., Crandall, Lynn, and Steward, W. G., 1938, Geolor:y and groundwater resources of the Snake River Plain in southeastern Idaho: U.S. Geol. Survey Water-Supply Paper 774, 268 p. [1939].

Thomas, C. A., Broom, H. C., and Cummans, J. E., 1963, Magnitude and frequency of floods in the United States, Part 13, Snake River basin: U.S. Geol. Survey Water-Supply Paper 1688, 250 p. [1964].

U.S. Bureau of Reclamation, 1959, Salmon Falls Project, Idaho: Reconnaissance Rept., Boise, Idaho, 79 p. 
U.S. Department of Agriculture, 1956, A report on the seepage los s study on the Salmon River canal system of the Salmon River Canal Co., Ltd., Hollister, Idaho: Twin Falls, Idaho, Soil Conservation Service, 20 p., January (mimeographed).

U.S. Geological Survey, 1956, Compilation of records of surface waters of the United States through September 1950, part 13, Snake River basin: U.S. Geol. Survey Water-Supply Paper 1317, 566 p.

1963, Compilation of records of surface waters of the United States, October 1950 to September 1960, part 13, Snake River basin: U.S. Geol. Survey Water-Supply Paper 1737, 282 p.

U.S. Public Health Service, 1962, Drinking water standards, 1962: U.S. Public Health Service Pub. 956, 61 p.

U.S. Salinity Laboratory Staff, 1954, Diagnosis and improvement of alkali soils: U.S. Dept. Agriculture Handb. 60, 160 p.

U.S. Weather Bureau, 1932, Climatic summary of the United States, Sec. 19 , Nev., U.S. Govt. Printing Office.

1937, Climatic summary of the United States, Sec. 6, Southern Idaho, U.S. Govt. Printing Office.

1957, Climatic summary of the United States, Supplement for 1931 through 1950, Nev.: Climatography of the United States, no. 11-22, U.S. Govt. Printing Office.

1958, Climatic summary of the United States, Supplement for 1931 through 1950, Idaho: Climatography of the United States, no. 11-8, U.S. Govt. Printing Office.

1959, Climate of the States, Idaho: Climatography of the United States, no. 60-10, U.S. Govt. Printing Office.

1962a, Climatological Data, annual summary, 1961, Idaho: vol. 64, no. 13. no. 13.

1962b, Climatological Data, annual summary, 1961, Nev.: vol. 76 , 1963a, Climatological Data, annual summary, 1962, Idaho: vol. 68, no. 13.

1963b, Climatological Data, annual summary, 1962, Nev.: vol. 77, no. 13.

1964a, Climatological Data, annual summary, 1963, Idaho: vol. 66, no. 13.

1964b, Climatological Data, annual summary, 1963, Nev.: vol. 78, no. 13.

$1964 \mathrm{c}$, Climatic summary of the United States, Supplement for 1951 through 1960, Idaho: Climatography of the United States, no. 86-8, U.S. Govt. Printing Office.

1965, Climatic summary of the United States, Supplement for 1951 through 1960, Nev.: Climatography of the United States, no. 86-22, U.S. Govt. Printing Office.

Warnick, C. C., and Johnson, A. A., 1955, Investigation of seepage losses from Salmon Falls Canal system; preliminary report: Idaho Univ. Eng. Expt. Sta., Spec. Research Proj. 47, 22 p.

Wing, Herbert, 1915, Tenth biennial report of the State Engineer of Idaho: Boise, Idaho, p. 138-145. 